\title{
Current challenges for explaining (ultra)high-pressure tectonism in the Pennine domain of the Central and Western Alps
}

\author{
Journal Article \\ Author(s): \\ Schenker, F.L.; Schmalholz, S.M.; Moulas, E.; Pleuger, J.; Baumgartner, L. P.; Podladchikov, Yuri Y.; Vrijmoed, J.; Buchs, N.; \\ Muntener, O.
}

Publication date:

2015-10

Permanent link:

https://doi.org/10.3929/ethz-a-010744267

Rights / license:

In Copyright - Non-Commercial Use Permitted

Originally published in:

Journal of Metamorphic Geology 33(8), https://doi.org/10.1111/jmg.12143

Funding acknowledgement:

335577 - Interplay between metamorphism and deformation in the Earth's lithosphere (EC) 


\title{
Current challenges for explaining (ultra)high-pressure tectonism in the Pennine domain of the Central and Western Alps
}

Filippo L. Schenker ${ }^{\mathrm{a}, \mathrm{b}}$, Stefan M. Schmalholz ${ }^{\mathrm{a}}$, Evangelos Moulas ${ }^{\mathrm{c}}$, Jan Pleuger ${ }^{\mathrm{d}}$, Lukas P. Baumgartner ${ }^{a}$, Yuri Podladchikov ${ }^{a}$, Johannes Vrijmoed ${ }^{c}$, Nicolas Buchs ${ }^{\mathrm{a}}$, Othmar Müntener ${ }^{\mathrm{a}}$

${ }^{a}$ Institute of Earth Sciences, University of Lausanne, Lausanne, Switzerland

${ }^{b}$ Institute of Earth Sciences, University of Applied Sciences and Arts of Southern Switzerland (SUPSI), Canobbio, Switzerland

'Department of Earth Sciences, ETH Zurich, Zurich, Switzerland

${ }^{d}$ Institute of Geological Sciences, Freie Universität Berlin, Berlin, Germany

\begin{abstract}
The Pennine domain of the Central and Western (PCW) Alps, including the Dora-Maira, Monte Rosa, Gran Paradiso, Adula/Cima Lunga nappes and the Zermatt-Saas Zone underwent Ultrahigh- or High-Pressure ((U)HP > 1.5 GPa) metamorphism during the Alpine orogeny. We review structural, petrological and geochronological data for the (U)HP units in the PCW Alps (i) to clarify the relationship between (U)HP metamorphism and deformation, (ii) to confront published exhumation models for the (U)HP units with the reviewed data, and (iii) to evaluate consequences of different pre-Alpine paleogeographic settings (Penrose-type ocean vs hyperextended margins) on the Alpine orogeny. The review indicates that (i) peak-pressures are recorded only in minor volumes of the corresponding tectonic nappes, (ii) (U)HP rocks occur within coherent and imbricate thrust sheets which show substantial pressure jumps, (iii) peakpressures are mostly associated with a top-to-the-foreland kinematics, (iv) decompression from (U)HP (4 to $>1.5 \mathrm{GPa}$ ) to greenschist- or amphibolite-facies ( 1 GPa) metamorphic conditions is fast $(<\sim 2 \mathrm{Ma})$, and (v) accreted fragments of the Alpine-Tethyan basins reflect Mesozoic hyperextended margins rather than mature Penrose-type oceans. The comparison of these characteristics with numerical exhumation models suggests that exhumation of (U)HP rocks by buoyancy-driven return flow within a subduction channel under near lithostatic pressure is unlikely because (i) models predict volumes of (U)HP rocks that are more than an order of magnitude larger as observed in the PCW Alps, and (ii) the required top-to-the-hinterland (U)HP kinematics in the hangingwall of (U)HP units has not been observed. Also, the buoyancydriven exhumation of individual crustal (U)HP units within weak $\left(\leq 10^{19}\right.$ Pas) and denser ( $>$ $\sim 3180 \mathrm{kgm}^{-3}$ ) rocks is questionable, because there is yet no evidence of such rocks around the (U)HP units. An alternative model, which could explain the main characteristics of the (U)HP units in the PCW Alps, is an orogenic wedge model that (i) involves dynamic stresses deviating from lithostatic pressure and (ii) is formed during the convergence of hyperextended margins. Deviations of dynamic stresses from the lithostatic pressure and local pressure variations cannot be excluded during the Alpine orogeny, but these deviations and variations have not been clearly identified until now.
\end{abstract}

Keywords: Central-Western Alps; non-lithostatic pressure; orogenic wedge; subduction channel; (ultra)high-pressure metamorphism 


\section{INTRODUCTION}

The Pennine domain of the Central and Western (PCW) Alps is built up of imbricate tectonic nappes whose structural evolution has been explained with models of orogenic wedges (Fig. 1a, e.g. Platt, 1986). In such models, tectonic nappes are formed at crustal depths ( $<\sim 60 \mathrm{~km})$ by ductile underplating and top-to-foreland piling. Metamorphic peak-pressure estimates in the PCW Alps are 1-2 GPa (e.g. Chinner \& Dixon, 1973; Ernst \& Dal Piaz, 1978; Dal Piaz et al., 1983; Oberhänsli et al., 1985; Heinrich, 1986), but the identification of coesite (Chopin, 1984) and recently diamond (Frezzotti et al., 2011) resulted in local peak-pressures estimates of 2-4 GPa (e.g. Reinecke, 1998; Rubatto \& Hermann, 2001; Frezzotti et al., 2011). These ultrahighPressure (UHP > 2.7 GPa) findings were arguments to reject orogenic wedge models (Jolivet et

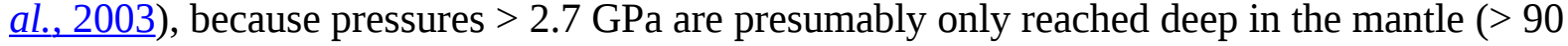
$\mathrm{km})$. Today, most geologists explain the structural evolution of the PCW Alps with subduction of continental and oceanic crust to mantle depths and subsequent exhumation by buoyancy-driven flow, which can occur by mainly three mechanisms: (1) continuous return flow of rocks in a subduction channel (Fig.1b, e.g. England \& Holland, 1979; Stöckhert \& Gerya, 2005), (2) upward flow of individual buoyant rock units within a denser material (so-called Stokes flow, Fig.1c, e.g. Burov et al., 2001), and (3) lithospheric extension and related upward flow caused by slab rollback (e.g. Beltrando et al., 2010). Mechanisms (1) and (2) are supported by numerical simulations driven by slab pull of the Tethys oceanic lithosphere (e.g. Stöckhert \& Gerya, 2005; Yamato et al., 2008; Butler et al., 2013, 2014). In such models metamorphic pressures recorded by ultrahigh- or high-pressure ((U)HP) crustal rocks were always close to the lithostatic pressure. In contrast to these "lithostatic subduction models", some studies argue that the Alpine orogeny may have been driven by compressive tectonic forces that produced local stresses, deviating $>50 \%$ from the actual lithostatic pressure (Schmalholz et al., 2014; $\underline{\text { Schmalholz \& }}$ Duretz, 2015). Hence the tectono-metamorphic evolution of the PCW Alps could be explained with an orogenic wedge similarly to (Platt, 1986) in which dynamic stresses deviate from the lithostatic pressure (termed here “dynamic orogenic wedge model”).

On the micro- and meso-scale, (U)HP rocks of the PCW Alps occur within restricted domains showing sharp contrasts in the recorded metamorphic pressure; for example, (i) within a garnet grain (Fig. 2a) where inclusions of quartz and coesite exist simultaneously (Lago di Cignana locality, Reinecke, 1998), (ii) at the meter-scale (Fig. 2b) between an eclogitic mafic boudin and a jadeite-absent metagranitic matrix (Adula/Cima Lunga nappe, Evans et al., 1979; Heinrich, 1982), (iii) at the decameter-scale (Fig. 2c) between a whiteschist lens and weakly deformed omphacite-absent metagranite (Monte Rosa nappe, Pawlig \& Baumgartner, 2001) and (iv) at the kilometer-scale (Fig. 2d) with the coesite-bearing orthogneisses and schists of the Brossasco-Isasca unit ( 4 GPa) tectonically inserted between the lower pressure ( 1.5 GPa) San Chiaffredo and Rocca Solei units (Dora Maira, Compagnoni et al., 2012). These recorded pressure differences are accompanied by metamorphic temperature variations.

This local occurrence of (U)HP rocks and minerals is usually explained by the fact that mineral assemblages record only part of the $P-T$ path that a rock undertakes. The details of the $P-T$ record depend on chemical compositions, the presence or absence of water and reaction kinetics. Hence the locally determined (U)HP conditions are extrapolated to the entire tectonic slice or even nappe that is assumed to have experienced the same deep burial and subsequent 
exhumation history (e.g. Chopin, 1984; Schreyer, 1995). In contrast, some studies argue that pressure acting in a rock mass does not need to be homogeneously distributed due to rheological heterogeneities, tectonic forces and volume changes that occur at depth (see Mancktelow (2008) and Moulas et al. (2013) for a recent review). If true, rock units may record different metamorphic pressures locally although they were at the same depth (e.g. Clark, 1961). Therefore, the preservation of different pressure can be envisaged to be due to either local retrogression due to limited fluid or slow prograde reaction or due to local deformation induced pressure variation.

Considering that recent numerical studies showing spatial pressure variations in rheologically heterogeneous materialss exhibited geometrical similarities with (U)HP occurrences of the PCW Alps (cf. Figs 2b, 2c with Fig. 4 of Moulas et al. (2014), this study aims to critically reevaluate conceptual and numerical models of formation and decompression/exhumation of (U)HP rocks by comparing field, petrological, geochronological and structural data on (U)HP rocks in the PCW Alps.

The comparisons between geological, conceptual and numerical models show that the exhumation mechanism of (U)HP rocks in the PCW Alps remains a controversial topic. We argue that the (U)HP rocks of the Dora Maira and Zermatt-Saas zones were unlikely exhumed within a continuous return flow in a subduction channel. The $P-T$ evolution and the exhumed (U)HP volumes suggest that (U)HP rocks exhume either by Stokes flow within a low viscosity and dense channel or in a dynamic orogenic wedge with local pressure variations. We favor the dynamic orogenic wedge model because it explains better the structural edifice of the PCW Alps.

\section{TECTONICS OF THE PENNINE DOMAIN OF THE CENTRAL AND WESTERN ALPS Overview}

The PCW Alps result from the closure of the Mesozoic Piemonte-Liguria basin(s) and the subsequent collision of the Adriatic (African) continental plate with several or a single composite plate, which comprised the European passive continental margin with promontories and basin(s) such as the Briançonnais swell and the Valais basin (e.g. Debelmas \& Lemoine, 1970; Tricart, 1984). Field relationships (Fig. 3) from top to bottom are (i.e. from southern to the northern paleogeographic positions): (1) The late Cretaceous Adria-derived Sesia-Lanzo domain and Dent Blanche nappe; (2) the ophiolitic Piemonte-Liguria zone (e.g. Zermatt Saas and Monviso zones), (3) the Paleogene Penninic nappes that include the southern European passive continental margin and the Briançonnais (e.g. Adula/Cima Lunga, Monte Rosa, Gran Paradiso and DoraMaira nappes). Accretion occurred during southeastward underthrusting of the Piemonte-Liguria basin(s) and migrated northward forming a S-SE dipping thrust wedge (e.g. Tricart, 1984; Platt, 1986).

Mid-Cretaceous mass-flow deposition (turbidites) on oceanic sequences probably indicates the beginning of the underthrusting of the Piemonte-Liguria ocean (Trümpy, 1973). Nappe emplacement and associated (U)HP metamorphism peaked at 75 -65 Ma in the SesiaLanzo zone (e.g. Regis et al., 2014) and migrated to the more external zones at 44-40 Ma in the Zermatt-Saas zone (e.g. Rubatto et al., 1998; Amato et al., 1999; Skora et al., 2006, 2009; de Meyer et al., 2014), at 43-42 Ma in the Monte Rosa nappe (e.g. Lapen et al., 2007), at 41-34 Ma in the Gran Paradiso nappe (e.g. Meffan-Main et al., 2004; Rosenbaum et al., 2012), at 35$32 \mathrm{Ma}$ in the Dora-Maira nappe (Rubatto \& Hermann, 2001) and at 44-37 in the Adula/Cima 
Lunga nappe (e.g. Becker, 1993; Herwartz et al., 2011). A review of ages of (U)HP metamorphism in the Alps is given by Berger \& Bousquet (2008) and Agard et al. (2009).

The (U)HP-bearing nappes: occurrence, textural relationships with the regional structures, peak $P$ and $T$ conditions, timing, and published exhumation models of (U)HP metamorphic rocks

In the Alps, a relatively large number of (U)HP units, both of continental and oceanic origin, has been identified (Fig. 2). The exhumation of such units is commonly restored in two-dimensional kinematic maps and profiles, which attempt to reconcile data consistently from various geological disciplines such as sedimentology, petrology, structural geology, geochemistry, and radiometric age dating. Among these, structural methods have the greatest potential to quantify the geometrical changes of individual tectonic units through time provided that sufficient strain data are available. For the (U)HP units in the Alps, however, this is not generally the case because remnants of (U)HP metamorphism and related structures are in most units restricted to volumetrically minor lenses while the country rocks provide a continuous record of pervasive structures that formed under regional greenschist- and amphibolite-facies conditions. In the following sections, we present the extent of the (U)HP rocks in different nappes and their textural relationship with the regional structures. We further review peak and, when available, decompression metamorphic conditions, metamorphic ages and exhumation models of (U)HP rocks.

\section{Dora-Maira (Briançonnais)}

The Penninic Dora-Maira massif consists of imbricated slices of continental crust with preAlpine metamorphic rocks (the micaschist), which were intruded by Permian granitoids (the metagranite), and with minor marbles and eclogites (Fig. 3, e.g. Vialon, 1966; Compagnoni \& Hirajima, 2001). The Dora-Maira unit extends $\mathrm{N}-\mathrm{S}$ and W-E over $\sim 50 \mathrm{~km}$ and $\sim 10 \mathrm{~km}$, respectively (Fig. 3). The UHP rocks are limited to the Brossasco-Isasca subunit ( $\sim 15$ wide x 2 $\mathrm{km}$ thick, Fig. 1d) in the South, which is sandwiched between lower grade metamorphic units of the Rocca Solei (RSU), San Chiaffredo (SCU), and Pinerolo subunits (Fig. 3, e.g. Compagnoni et al., 2012). Peak metamorphic pressure in the Brossasco-Isasca micaschists are derived from phengite + garnet \pm kyanite \pm jadeite + relict coesite inclusions in garnet and lenses of eclogites with relictic coesite in garnet, omphacite and zoisite. Peak pressure conditions in the metagranite are derived from their mineral assemblage jadeite + zoisite + garnet \pm high-silica phengite and polygonal quartz aggregate (interpreted as retrogressed coesite). The "typical” UHP white schists (Chopin, 1984) crop out within the granitoids in 10-15 m thick and $50 \mathrm{~m}$ long metasomatically altered zones (Ferrando et al., 2009). Deformation at UHP conditions was heterogeneous and partitioned between shear zones and regions of almost no strain where magmatic textures with randomly oriented K-feldspar and xenoliths are preserved (Henry et al., 1993). The kinematic relationship during UHP metamorphism is unclear because of unknown bulk rotation of the UHP structures during the later top-to-the-foreland (west) greenschist-facies shearing (Michard et al., 1993; Avigad et al., 2003). Despite strain localization, the original intrusive contacts of the metagranite with the micaschist country rock are preserved (Fig. 3, Compagnoni et al., 2012) suggesting that the Brossasco-Isasca unit remained rather coherent during burial and exhumation.

Peak metamorphic conditions are 3.6-4.5 GPa/ 730 ${ }^{\circ} \mathrm{C}$ in the Brossasco-Isasca unit (e.g. Schertl et al., 1991; Hermann, 2003; Castelli et al., 2007), $1.5 \mathrm{GPa} / 550^{\circ} \mathrm{C}$ in the Rocca Solei 
unit (Chopin et al., 1991; Matsumoto \& Hirajima, 2000), and the San Chiaffredo unit (Compagnoni, 2003; Compagnoni \& Rolfo, 2003) and $\sim 0.8 \mathrm{GPa} / 400{ }^{\circ} \mathrm{C}$ in the Pinerolo unit (Chopin et al., 1991; Avigad et al., 2003). Ultrahigh pressure metamorphism of the Brossasco-

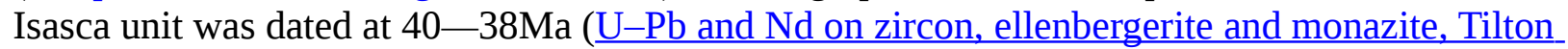

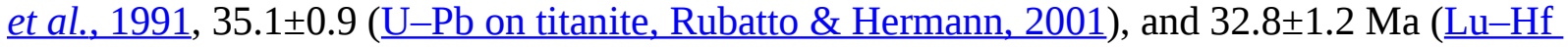
on garnet, Duchêne et al., 1997). According to Rubatto \& Hermann 2001, conditions of ca. 1 $\mathrm{GPa} / \mathrm{ca} .550{ }^{\circ} \mathrm{C}$ were established at $32.9 \pm 0.9$ Ma resulting in vertical exhumation rates from UHP condition of $3.4 \mathrm{~cm} / \mathrm{a}$.

Several exhumation mechanisms have been put forward: (i) unroofing of the upper and middle crust during orogenic collapse (Avigad et al., 2003), (ii) return flow in a subduction channel (Ford et al., 2006; Butler et al., 2013, 2014), (iii) extrusion of a UHP slice from the subduction channel (e.g. Wheeler, 1991) driven by buoyancy (Stoke flow, Yamato et al., 2008). Given the fast exhumation rates, most authors favor either overall return flow or Stokes flow as an exhumation mechanism (e.g. Rubatto \& Hermann, 2001). In both cases, the Brossasco-Isasca unit should be roofed by top-to-the-hinterland faults that accommodated the exhumation from UHP condition. These top-to-the-hinterland faults were not observed on the roof of the Brossasco-Isasca unit (e.g. Avigad et al., 2003) but it was argued that they were obliterated by subsequent greenschist deformation (Michard et al., 1993).

\section{Monte Rosa and Gran Paradiso nappes (Briançonnais)}

The Monte Rosa and Gran Paradiso continental nappes are separated from each other by an axial depression in which the overlying Zermatt-Saas zone crops out (e.g. Argand, 1916). The Monte Rosa nappe is comprised largely of pre-Alpine gneissic continental basement rocks represented by high grade (sillimanite $+\mathrm{K}$-feldspar) paragneisses and cordierite bearing migmatites (Bearth, 1952), which were intruded by granitic to granodioritic plutonic rocks at $\sim 270 \mathrm{Ma}$ (Dal Piaz \& Gatto, 1963; Pawlig \& Baumgartner, 2001). The Alpine peak-pressure metamorphism is characterized by: (i) Partial to complete transformation of the pre-270 Ma paragneiss and anatectic migmatites to garnet (mostly inherited) + phengite \pm kyanite + chloritoid + Mg-chlorite whiteschists. (ii) Pseudomorphic replacement of pre-Alpine prismatic sillimanite and cordierite by fine aggregates of kyanite and kyanite + garnet. The typical HP assemblage in metapelites is phengite + garnet + chloritoid + kyanite + rutile + quartz ( \pm carbonate and $\mathrm{Na}$-amphibole). (iii) Eclogitization of mafic boudins (garnet + omphacite \pm lawsonite pseudomorph + amphibole + rutile + white mica \pm quartz assemblage). (iv) Whiteschist lenses (Fig. 2c, talc + chloritoid + kyanite) within almost undeformed granites (Bearth, 1952; Dal Piaz, 1971, Pawlig, 2001; Dal Piaz \& Lombardo, 1986; Borghi et al., 1996; Lapen et al., 2007). Notably, no evidence of highpressure breakdown of plagioclase to sodic pyroxene + zoisite + quartz has been reported in the weakly deformed portions of Monte Rosa granite.

Eclogites record the highest reported pressures from the Monte Rosa nappe of 2.4-2.7 $\mathrm{GPa} / 500-600{ }^{\circ} \mathrm{C}$ (Le Bayon et al., 2006b; Gasco et al., 2011). Lower peak pressures were obtained from eclogite boudins, metapelites and whiteschists at $0.9-1.6 \mathrm{GPa} / 420-570{ }^{\circ} \mathrm{C}$ (Chopin \& Monié, 1984; Dal Piaz \& Lombardo, 1986; Borghi et al., 1996; Lapen et al., 2007). High-Pressure metamorphism in the Monte Rosa has been dated at $42.6 \pm 0.6 \mathrm{Ma}$ ( $\underline{\mathrm{U}-\mathrm{Pb} \text { dating }}$ on rutile, Lapen et al., 2007) and decompression from P-peak condition at 46-31 Ma (Th-U-Pb dating on monazite, Engi et al., 2001b). 
In general, the $P-T-t$ paths of the Gran Paradiso nappe are similar to the ones of the Monte Rosa nappe (e.g. Gabudianu Radulescu et al., 2009) with metamorphic peak conditions of 2.6-2.7 GPa $/ 580$ - $600^{\circ} \mathrm{C}$ (Le Bayon et al., 2006a; Gasco et al., 2010). Radiometric ages for high-pressure metamorphism in the Gran Paradiso gave $43.0 \pm 0.5 \mathrm{Ma}(\underline{\mathrm{Rb}-\mathrm{Sr} \text { on apatite- }}$ phengite pair, Meffan-Main et al., 2004), 33.7 $\pm 1.6 \mathrm{Ma}$ (U-Pb on Allanite, Gabudianu Radulescu et al., 2009) and 41-34 Ma (ㅁ-Sr and Ar-Ar on white micas, Rosenbaum et al., 2012).

Most tectonic models favor exhumation of the Monte Rosa and Gran Paradiso nappes as Stokes bodies or diapirs (e.g. Lapen et al., 2007). Nevertheless, between the Gran Paradiso and Monte Rosa nappes and the above laying Zermatt-Saas zone, there is no evidence of top-to-thehinterland normal faults responsible for the extrusion from (U)HP condition (e.g. Pleuger et al., 2005). Therefore, according to these models, the main normal fault accommodating the extrusion of the (U)HP units has to be located above the Zermatt-Saas zone.

\section{The Zermatt-Saas Zone (Piemonte-Liguria Oceanic basin)}

The Zermatt-Saas zone consists of accreted slices and blocks of eclogite-facies metabasalts, metagabbros, serpentinites, metasediments and minor mélange zones containing blocks of the above mentioned rocks and metavolcanics attributed to the Mesozoic Piemonte-Liguria basin (e.g. Bearth, 1967; Ernst \& Dal Piaz, 1978). These slices are roughly parallel to the boundaries of the Zermatt-Saas zone, for example (i) basal serpentinites strike over $20 \mathrm{~km}$ parallel to the tectonic contacts (Fig. 5a), (ii) the $100 \mathrm{~m}$ thick Spitze Fluh flasergabbro in the Täsch valley is mapped over $5 \mathrm{~km}$ (Fig. $5 \mathrm{~b}$ and c) and (iii) at the outcrop-scale this gabbroic slice is mostly undeformed with exception of some local necking (Buchs, 2013). These observations suggest that the Zermatt-Saas zone is a coherent imbrication (e.g. Angiboust \& Agard, 2010) of a complex pre-collisional tectono-sedimentary setting of the Piemonte-Liguria basin (Rubatto et al., 1998; Mahlen et al., 2005). The Zermatt-Saas zone tectonically lies above the Monte Rosa nappe and below the Tsaté nappe (Fig. 5). The Tsaté nappe has also Piemonte-Liguria affinity

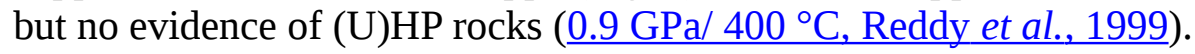

The peak blueschist- to eclogite-facies metamorphism is pervasive within the mafic rocks. Prasinites attest retrogression to greenschist-facies conditions (Bearth, 1959). Diamond and coesite point to UHP peak pressure conditions (Groppo et al., 2009; Frezzotti et al., 2011) of the associated eclogitic mineral assemblages (e.g. Bearth, 1962, 1967; Chinner \& Dixon, 1973; Oberhänsli, 1982). The metasediments underwent peak condition similar to those of the metabasites (e.g. Angiboust et al., 2009) locally preserving coesite as garnet inclusions (Reinecke, 1998). Strain partitioning during peak conditions is attested by the wide range of the aspect ratios of pillows in eclogitic basalts. Locally, (U)HP assemblages in the metagabbro grew statically forming pseudomorphic textures after magmatic minerals (e.g. flasergabbros, $\underline{\text { Chinner }}$ \& Dixon, 1973; Barnicoat \& Fry, 1986) .

Peak metamorphic conditions of $>3.2 \mathrm{GPa} / \mathrm{ca} .600^{\circ} \mathrm{C}$ are proposed based on inclusions of diamond in garnet (Frezzotti et al., 2011). In the other associated units, peak mineral assemblages show lower pressure estimates of $1.5-2.8 \mathrm{GPa} / 575-610{ }^{\circ} \mathrm{C}$ (e.g. Barnicoat \& Fry, 1986; Ganguin, 1988; Lapen et al., 2003; Bucher, 2005; Angiboust et al., 2009). Peak conditions have been dated between 50 and 40 Ma with different radiometric systems ( $\underline{\mathrm{U}-\mathrm{Pb} \text { in zircon, }}$ Rubatto et al., 1998; Sm-Nd in garnet, Amato et al., 1999; Lu-Hf and Sm-Nd in garnet, Lapen et al., 2003). Based on detailed trace element zoning and dating studies on garnets peak and 
$\mathrm{Rb} / \mathrm{Sr}$ dating of mica included in garnets, peak metamorphic conditions were reached between 42-40 Ma ago (Lapen et al., 2003; Skora et al., 2006, 2009; de Meyer et al., 2014). In places, the increase of the pressure in the Zermatt-Saas zone was protracted over 15-30 Ma according to Lu-Hf garnet ages (Skora et al., 2009). Isothermal decompression to greenschist-facies conditions (Reinecke, 1998; Cartwright \& Barnicoat, 1999) was fast (between 3 and < 1 Ma) and uniform in the entire Zermatt-Saas zone (de Meyer et al., 2014).

According to most reconstructions, the Zermatt-Saas zone was extruded in a subduction channel driven by the positively buoyant continental crust of the underlying Monte Rosa and Gran Paradiso nappes (e.g. Lapen et al., 2007). According to Reddy et al. (1999), exhumation was accommodated by extension along top-to-the-hinterland shear zone roofing the ZermattSaas Zone (Gressoney shear zone). However, such extension postdate greenschist- to lower blueschist-facies (and not eclogite-facies) top-to-the-foreland shearing (e.g. Pleuger et al., 2007).

\section{Adula/Cima Lunga nappes (European Margin)}

The Subpenninic Adula nappe consists mostly of ortho- and paragneisses; the latter contain subordinate volumes (decimeter to hectometer in size, Fig. 2b) of mafic and ultramafic rocks. Eclogite facies metamorphism is restricted to mafic and ultramafic and few whiteschist lenses (Heinrich, 1982; Meyre et al., 1999). A very strong shape- and lattice-preferred orientation of omphacite (Pleuger et al., 2003) attests for HP deformation attributed to top-to-the-foreland thrusting (Meyre \& Puschnig, 1993). Cavargna-Sani et al. (2014) recognized early top-to-thehinterland kinematics of unclear metamorphic condition interpreted as the major shear event accommodating exhumation. Nevertheless, the eclogitic lenses are variably overprinted by structures related to top-to-the-foreland thrusting (Meyre \& Puschnig, 1993; Pleuger et al., 2003). According to Nagel et al. (2002), extensional structures developed only after pressure

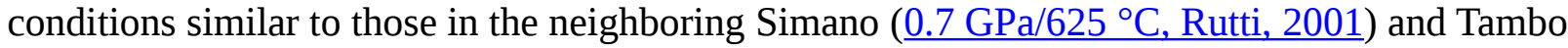

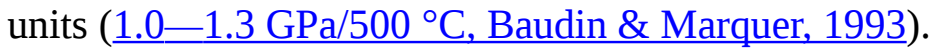

The mafic lenses define a southwards pressure increase from $1.2-1.7 \mathrm{GPa} / 500-640{ }^{\circ} \mathrm{C}$ to 2-2.5 GPa/750 - $800{ }^{\circ} \mathrm{C}$ (e.g. Heinrich, 1986; Dale \& Holland, 2003). High-Pressure metamorphism peaked at $37.1 \pm 0.9 \mathrm{Ma}$ and $38.8 \pm 4.3 \mathrm{Ma}$ in the central nappe and at $34.1 \pm 2.8$ Ma in the southern nappe (Herwartz et al., 2011; Sandmann et al., 2014). The latter age was interpreted as a minimum age because the rock may have been re-equilibrated under temperatures higher than the closure temperatures in the Lu-Hf garnet system $\left(\geq 630^{\circ} \mathrm{C}\right.$, Skora et al., 2008). Later, before ca. 32 Ma, i.e. the age of emplacement of the Bergell tonalite (von Blanckenburg et al., 1992), the Adula nappe must have been decompressed to about $0.8 \mathrm{GPa}$ in the north (Löw, 1987) and about 1.0 GPa in the south (Nagel et al., 2002).

Based on $P-T$-trajectories of rocks and on lithological heterogeneity in the southern Adula Nappe, Engi et al., (2001a) suggested that the Adula Nappe is a tectonic mélange formed in a fossil tectonic accretion channel whose exhumation to mid-crustal levels was accommodated by extrusion. This is inconsistent with various lines of evidence indicating that the Central and Northern Adula nappe was a coherent unit during Alpine orogeny (e.g. Cavargna-Sani et al., 2014). In the model of Schmid et al. (1996), the Adula nappe is considered to be coherently exhumed within a subduction channel. The extrusion models require top-tothe-hinterland, i.e. top-to-the-south faulting in the hanging wall of the exhuming nappe. 
However, the shear sense of syn-decompressional faulting between the Adula Nappe and the overlying Misox Zone is top-to-the-foreland according to Nagel, et al. (2002) and Pleuger et al. (2003). Froitzheim et al. (2003) suggested a scenario with two different Alpine south-dipping subduction zones, with the northern one subducting the European margin, including the Adula nappe. There is, however, little evidence for two Alpine subduction zones.

\section{DISCUSSION}

There are several common features of the (U)HP metamorphism in the PCW Alps: (i) Recorded peak pressures are confined to minor volumes $\left(\mu \mathrm{m}^{3}\right.$ to few $\mathrm{km}^{3}$ ) of the nappes. (ii) (U)HP mineral assemblages grew both during nearly static conditions and during deformation. (iii) The oldest structures postdating peak-Pressure assemblage are related to top-to-the-foreland shearing. (iv) (U)HP rocks are included in large-scale thrust sheets. (v) According to the most recent geochronological data, decompression from (U)HP rocks to greenschist- or amphibolitefacies metamorphic conditions was fast and took place in less than $2 \mathrm{Ma}$. For each of the presented features, the application of conventional tectonic exhumation models raises specific problems that we will discuss in this section.

Conflicting models for $(U) H P$ rocks within nappes: limited fluid and/or reaction kinetics vs. local pressure variation

The local character of the (U)HP rocks in the PCW Alps (Fig. 1) is at odds with most tectonic interpretations that exhume large (U)HP terranes. Most interpretation assume that the local peakpressures recorded by minerals are the peak pressures experienced by the entire nappe. This generalization is explained by the fact that mineral assemblages of large volumes of the nappe did not record the pressure peak of the $P-T$ path that the nappe undertook. Since individual metamorphic paragenesis are rarely datable, two end-member scenarios may be envisaged: (1) the lack of fluids and/or slow reaction kinetics limits the reaction rates to such an extent that newly attained $P-T$ conditions are not recorded throughout a rock's metamorphic history. As a result, different lithologies or even different portions of the same rock record different parts prograde to peak to retrograde - assemblages. As is commonly assumed (e.g. Spear, 1995); (2) the pressure experienced by the rocks is heterogeneously distributed a given time during the evolution of the rock, and it is this which the rocks record.

In the first case, our knowledge about kinetics of mineral reactions for geological conditions and time scales limits the quantitative determination of the whole $P-T-t$ path. More specifically, the (post) Variscan metagranites of the Monte Rosa, Adula, and Cima Lunga units did not grow new mineral assemblages until partial hydration occurred during greenschist and amphibolite-facies conditions (e.g. Heinrich, 1982). The basement rocks consisting of granitic and high-T metamorphic rocks did not contain abundant water in minerals at the beginning of Alpine metamorphism, resulting in fluid-absent conditions for much of the Alpine metamorphic history.

In the second case there are two critical questions: (i) how large are pressure variations and (ii) how long were they sustained so that they could be recorded by the mineral assemblage (c.f. Brown, 2014; Moulas et al., 2014). (i) The magnitude of pressure variations depends on the rheology and strength of the considered rocks. As a first approximation, the higher the differential stress rocks can support, the higher the pressure variations can be (e.g. Petrini \& Podladchikov, 2000). For example, a relative strong mafic boudin included in a weak gneissic 
matrix (e.g. the eclogites of Adula/Cima Lunga, Fig. 2b) will experience over- or underpressures that are in the order of the differential stress (Mancktelow, 1993; Moulas et al., 2014). In addition, it has been demonstrated that even if parts of the rock cannot support high differential stress (e.g. weak inclusions such as the white schist in the metagranite from Monte Rosa, Fig. 2c), the pressure can still vary as a result of force balance (c.f. Mancktelow, 1993). This concept has been applied from the mineral scale (Schmid \& Podladchikov, 2003; Tajčmanová et al., 2014) to the scale of the lithosphere (Schmalholz \& Podladchikov, 2013; Schmalholz et al., 2014). (ii) The pressure variations within regions that have heterogeneous rheologies can persist for as long as the compression persists (Moulas et al., 2014). Since the duration of the metamorphic/deformation stage in the Zermatt-Saas zone lasted for at least 1530 Ma (Skora et al., 2009), metamorphic pressures different from lithostatic cannot be excluded.

\section{Coherency of (U)HP terranes and P-peak metamorphism during deformation}

The metamorphic terranes containing (U)HP rocks are not incoherent large-scale tectonic mélanges (Fig. 4). These field observations have constraining implications since in subduction channel models it is expected that (U)HP rocks were exhumed in a low viscosity channel that generates diapirs, plumes and large-scale curl (e.g. Stöckhert \& Gerya, 2005; Butler et al., 2013, 2014), which is inconsistent with the lithological coherency of (U)HP terranes.

In addition, there is contradiction between petrological and geodynamical arguments. To explain the local occurrence of (U)HP rocks embedded within large volumes of lower-grad rocks, some petrologists argue that the embedding lower-grade rocks have been dry so that (U)HP equilibria could not have been attained because the kinetics of mineral reactions were sufficiently slow (e.g. Schreyer, 1995). This would for example and account for the absence of jadeite in the Mt. Rosa, Gran Paradiso, and Adula nappes. Dry rocks are usually mechanically strong (cf. rheologies of wet and dry minerals, Rybacki \& Dresen, 2000; Bürgmann \& Dresen, 2008; Karato, 2010), which would explain the coherency of the exhumed tectonic units.

However, to exhume (U)HP rocks in a subduction channel by buoyancy large volumes of crustal rocks must be weak. Hence, some numerical studies utilize wet (weak) rheologies (e.g. wet quartzite flow laws) for crustal rocks exhuming and embedding (U)HP rocks (e.g. Butler et al., 2013) see geodynamic section below.

The absence of $(U) H P$ normal faults accommodating the exhumation of the nappes In the Adula nappe, Dora-Maira massif, and Zermatt-Saas zone the oldest post-peak-pressure structures are related to top-to-the-foreland shearing (e.g. Steck \& Hunziker, 1994). Such shearing is related to thrusting rooted in the hinterland of the respective units. This contrasts most extrusion models that accommodate 50 -60 km of exhumation from the (U)HP conditions along normal faults roofing the (U)HP units (Wheeler, 1991; Schmid et al., 1996). There are two potential solutions that can be envisaged: (i) Exhumation was accommodated by a large-scale normal fault which has been completely overprinted by later deformational stages. (ii) These (U)HP normal faults did not exist. Peak pressures obtained in the volumetrically minor (U)HP rocks (Fig. 1) cannot be extrapolated to the entire nappe and reflect local overpressure (Pleuger \& Podladchikov, 2014).

Time scale of pressurization and decompression At least for the Zermatt-Saas zone, the prograde pressurization was slow and occurred within 15-30 Ma (Skora et al., 2009). Decompression from (U)HP to greenschist- or amphibolitefacies metamorphic conditions for the Adula, Dora-Maira and Zermatt-Saas zone occurred in < 
2 Ma (Lapen et al., 2003; Skora et al., 2009). Assuming lithostatic pressure for the Dora-Maira example, the resulting vertical exhumation rates of the (U)HP rocks are $\sim 3.4 \mathrm{~cm} / \mathrm{a}$ (e.g. Rubatto

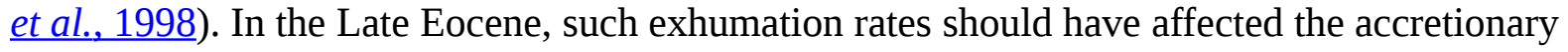
wedge dynamics by forming topography and increased erosion. Nevertheless, proluvial sediments typical of a growing topography were deposited only later in the Molasse in the middle Oligocene (e.g. Trümpy \& Homewood, 1980; Spiegel et al., 2000). Therefore, the surface effects of extremely fast exhumation of (U)HP rocks within a subduction channel are missing in the sedimentary record. In contrast, numerical models reproducing overpressure within shear zones show a slow buildup of the pressures followed by an extremely fast decompression $(<1-$ $2 \mathrm{Ma}$ ) accompanied by a constant exhumation rate that does not increase the erosion (Schmalholz et al., 2014).

\section{Geodynamics}

Continuous return flow within a subduction channel

The driving force for the exhumation by return flow in a subduction channel is buoyancy. The average exhumation velocity parallel to the channel is (England \& Holland, 1979)

$$
\bar{v}=\frac{\Delta \rho g \sin (\theta) h^{2}}{12 \eta}
$$

where $\Delta \rho$, g, $\theta$, $h$ and $\eta$ are the density difference between lighter crustal rocks inside the channel and heavier mantle rocks outside, the gravitational acceleration, the dip angle of the channel, the channel thickness and the effective channel viscosity, respectively. For the Brossasco-Isasca unit, an exhumation velocity of $3.4 \mathrm{~cm} / \mathrm{a}$ (Rubatto \& Hermann, 2001) in a 10 $\mathrm{km}$-thick channel which is inclined by $45^{\circ}$ and a density difference of $\sim 225 \mathrm{kgm}^{-3}$ ( $\rho_{\text {mantle }}-\rho_{\text {Brossasco- }}$ Isasca unit $=3400\left[\mathrm{kgm}^{-3}\right]-3175\left[\mathrm{kgm}^{-3}\right]$, Table 1$)$ requires an effective channel viscosity of $\sim 1.2 \times 10^{19}$ Pas (Eq. 1). The average shear strain rate in the channel can be estimated by the ratio of exhumation velocity to half the channel thickness which yields $\sim 2 \times 10^{-13} \mathrm{~s}^{-1}$. The product of viscosity and strain rate yields an average stress of $\sim 2.6 \mathrm{MPa}$ in the channel. These simple estimates agree with values of thermo-mechanical models which predict subduction channel viscosities of $\sim 10^{19}$ Pas (e.g. Gerya et al., 2008), strain rates of $\sim 10^{-14} \mathrm{~s}^{-1}$ (e.g. Burov et al., 2001) and stresses between 2-20 MPa (e.g. Butler et al., 2014).

The return flow injects the entire rock volume from the subduction channel into the orogenic wedge (Fig. 6). Assuming lithostatic pressure, the Brossasco-Isasca unit was exhumed from $120 \mathrm{~km}$ to $45 \mathrm{~km}$ (pressure difference between of the Rocca Solei and San Chiaffredo units, and the Brossasco-Isasca unit), and the UHP unit in the Zermatt Saas zone from 80-100 $\mathrm{km}$ to $30 \mathrm{~km}$ (pressure difference between Tsaté nappe and the Zermatt Saas zone). A $10 \mathrm{~km}$ thick channel related to the exhumation of the Brossasco-Isasca unit would have extruded 1060 $\mathrm{km}^{2}$ (in a 2-D cross section) of rocks with peak pressures between 1.5 and 4.0 GPa, and 510 $\mathrm{km}^{2}$ of rocks with pressures $>2.7 \mathrm{GPa}$ (UHP rocks, Fig. 6). These values correspond to a UHP unit which is $\sim 50 \mathrm{~km}$ long and $10 \mathrm{~km}$ thick. In contrast, for the Dora-Maira massif no rocks with peak pressures between 1.5 and $3.5 \mathrm{GPa}$ have been reported and the BIU is only $\sim 8 \mathrm{~km}$ long (parallel to the stretching lineation) and 1-2 km thick ( $\sim 2 \mathrm{~km}^{2}$, see Fig. 4). Similarly, to exhume the Zermatt Saas zone the channel should have injected into the orogenic wedge a HP unit that is $\sim 70 \mathrm{~km}$ long and $\sim 10 \mathrm{~km}$ thick (700 km²) with peak pressures between 0.9 and $2.6 \mathrm{GPa}$. In 
contrast, the mapped part of the Zermatt-Saas zone is $\sim 15 \mathrm{~km}$ long (parallel to the stretching lineation) and $\sim 2 \mathrm{~km}$ thick ( $\left.30 \mathrm{~km}^{2}\right)$. Furthermore, a natural subduction channel should be a three-dimensional object, that is, should have a lateral out-of-section extent. Therefore, return flow from depths $>\sim 80 \mathrm{~km}$ would be expected for the Dora-Maira massif also along strike (Fig. 3). However, there is currently no evidence for UHP rocks in the Dora Maira massif north and south of the Brossasco-Isasca unit.

Return flow in a channel only works if both sides of the channel are open and rocks can flow through the channel. This implies that rocks intrude the orogenic wedge as buoyancydriven plumes (Fig. 6, Butler et al., 2013, 2014). Low viscosity plumes generate significant vorticity, i.e. local spinning motion. Consequently, rock units from different crustal (sedimentary cover or basement) and paleo-geographic domains would be mixed during the return flow. However, the overall nappe geometry in the PCW Alps is a coherent and imbricate nappe stack with internal domains thrusted onto more external paleogeographic domains.

In summary, return flow in a subduction channel predicts (i) volumes of (U)HP rocks which are one to two orders of magnitude larger than the reported (U)HP volumes, (ii) structures which disagree with the observed imbricate and coherent nappe stack, (iii) the stresses that are too low.

\section{Exhumation of individual buoyant bodies: the Stokes flow}

Several studies argue that (U)HP rocks are exhumed in a subduction setting but that the driving force is the density difference between buoyant crustal rock units and denser surrounding rocks (e.g. Burov et al., 2001; Yamato et al., 2008), which is referred to as Stokes flow (e.g. Burov et al., 2001, 2014). The formula to calculate the exhumation velocity is

$$
v=\frac{2 \Delta \rho g a^{2}}{9 \eta}
$$

where $\Delta \rho$, $a$ and $\eta$ are now the density difference between a light and denser rock unit, the characteristic size of the light rock unit and the effective viscosity of the denser rocks. In general, Stokes flow does not require a channel. However, for the application to the PCW Alps a channel seems necessary to guide the exhuming UHP rocks back to lower-pressure rocks from the same paleogeographic domain (Fig. 7). If a channel does not exist, then (U)HP rocks would exhume vertically and intrude into the upper plate (Fig. 7, Yamato et al., 2008; the trans-lithospheric diapirism of Sizova et al., 2014). In the Alps, no exhumed (U)HP metamorphic rocks were found in the upper plate.

Although Eqs. 1 \& 2 are similar, the corresponding channel dynamics are significantly different. In the Stokes flow model, the exhumation velocity of the rock unit is much higher than the velocity in the channel. We apply in Eq. 2 estimates for the Brossasco-Isasca unit with an exhumation velocity of $\sim 3.4 \mathrm{~cm} / \mathrm{a}$, a density difference of $\sim 225 \mathrm{kgm}^{-3}$ and a characteristic size of 6’680'000 $\mathrm{m}^{2}$ (Table 1) which yields an effective viscosity of $\sim 3.4 \times 10^{18}$ Pas. For the Zermatt Saas Zone, an exhumation velocity of $1-4 \mathrm{~cm} / \mathrm{a}$ (Lapen et al., 2003; de Meyer et al., 2014), a density difference of $\sim 220 \mathrm{kgm}^{-3}$ and a characteristic size of 8’282'000 $\mathrm{m}^{2}$ (Table 1) yields an effective viscosity of $3.1 \times 10^{18}-1.2 \times 10^{19}$ Pas. Equation 2 implies that the channel rocks are denser than the (U)HP unit and have low viscosities between $10^{18}-10^{19}$ Pas. In the field, there is 
no evidence of such heavy and weak rocks. The Brossasco-Isasca unit is surrounded by gneisses with densities of $2600-2700 \mathrm{kgm}^{-3}$ and the Zermatt Saas Zone by the Monte Rosa nappe with densities of $2600-2700 \mathrm{kgm}^{-3}$ and the greenschist to lower blueschist facies-metamorphic Tsaté unit. Also, the surrounding rocks cannot be serpentinite which would have an appropriate viscosity but too low densities of $\sim 2700 \mathrm{kgm}^{-3}$.

With respect to field observations, the exhumation of (U)HP rocks by Stokes flow encounters less problems than the return flow model in a subduction channel, especially because Stokes flow does not predict enormous volumes of (U)HP rocks being injected the crust, which have not been found in the Alps. Nevertheless, to exhume the (U)HP volumes of the PCW Alps, specific sizes, densities and viscosities have to be applied. Rocks which could have been the dense and weak surrounding material enabling Stokes flow have not been reported yet - it is not the serpentinite surrounding the blocks!

Mechanical consequences on Alpine orogeny of pre-Alpine paleogeographic setting: drifted vs. hyperextended margins

Numerical models which study the exhumation of the (U)HP rocks usually assume a Penrosetype oceanic lithosphere (end-member 1, Fig. 8a, Anonymous, 1972) whose negative buoyancy (Cloos, 1993) drives and controls the burial and exhumation of (U)HP rocks by slab pull and slab roll back (e.g. Rosenbaum \& Lister, 2005). In the case of the pre-Alpine Mesozoic geodynamic setting of the Tethyan realm, the European and Adriatic plates have been separated by two oceanic domains (a larger Piemont Ocean and a smaller Valais Ocean) separated by the Briançonnais microcontinent (end-member 1, Figs 8a, 8c, e.g. Rosenbaum \& Lister, 2005). During subduction such a lithosphere sinks into the asthenosphere (e.g. Handy et al., 2010).

In the PCW Alps there is no evidence of fragments of a Penrose-type oceanic lithosphere with a prominent mafic crust (Lemoine et al., 1987). Field observations argue instead in favor of a distributed extension that was accommodated by a series of low-angle detachment systems that thinned the continental crust and finally led to the exhumation of subcontinental mantle on the sea-floor (end-member 2, Fig. 8b, 8d, e.g. Lemoine et al., 1987; Mohn et al., 2010). The upper 3 -5 kilometres of the exhumed subcontinental mantle have been partially to completely serpentinized (e.g. Minshull et al., 1998). During extension, melts rising from the decompressing asthenosphere and percolating through the subcontinental mantle modified the mantle mineralogy mainly by precipitating up to $15 \mathrm{vol} \%$ of plagioclase at depth $<30 \mathrm{~km}$ (Müntener et al., 2004). This refertilization process was heterogeneous and did only affect some parts of the lithospheric mantle (Fig. 7b, c.f. Müntener et al., 2004). Magmatic rocks form kilometer-scale gabbroic bodies within subcontinental or refertilized mantle rocks, and locally pillow basalts with MORB-like (Schaltegger et al., 2002) signatures lie on top of exhumed and altered mantle rocks (Fig. 8d, e.g. Lagabrielle et al., 1984; Pfeifer et al., 1989). This lithostratigraphy of the lithosphere is similar to the "transitional crust" of (loos, 1993) that may have a less negative or even neutral buoyancy. The buoyancy of the lithosphere of end-member (2) is likely less negative than the one of end-member (1), which is commonly used in subduction zone modeling, because of the refertilized plagioclase bearing mantle, widespread serpentinization in the top most 5 kilometers and the missing thick mafic oceanic crust. Consequently, this lithosphere will not generate significant slab pull enhancing burial of crustal rocks to mantle depths $(>60 \mathrm{~km})$. In that case, the main driving forces for the Alpine orogeny were probably farfield intra-plate tectonic stresses related to the opening of the Atlantic. 
The evolution of Alpine structures and their formation mechanism is arguably different, for the two end-members (1) or (2). We argue that there was no typical oceanic slab-controlled subduction in the PCW Alps because the subduction of a mature oceanic lithosphere extending over several hundred of $\mathrm{km}$ is questionable: (i) Mature oceanic lithosphere is commonly observed for a fast spreading ridge setting ( $>50 \mathrm{~mm} / \mathrm{a}$, Sinton \& Detrick, 1992). However, plate reconstructions show that the Alpine Tethys Ocean was limited to $<20 \mathrm{~mm} / \mathrm{a}$ (e.g. Vissers et al., 2013). With this spreading velocity (typical for slow- and ultra-slow spreading ridges) extensional faults continue to exhume (subcontinental) mantle and develop oceanic core complex type ocean basins with minor magmatic activity and continuous serpentinization (e.g. Lagabrielle et al., 2015). (ii) The subduction of mature oceanic lithosphere in subduction zones generates arc magmatism. However, in the Alps, magmatism with an 'arc' signature is scarce and restricted to a few plutons and dikes ranging in age from 42-28 Ma, with ages generally older in the southeast than in the northwest (e.g. Bergomi et al., 2014). While the Adamello massif covers the age (e.g. 42 to $29 \mathrm{Ma}$ ) between subduction and collision the Bergell pluton, other smaller plutons in the western Alps (e.g. Biella) and the associated volcanoclastic sediments are mostly interpreted as syn-collisional between 33 and 30 Ma, (e.g. Sciunnach \& Borsato, 1994; Von Blanckenburg \& Davies, 1995; Kapferer et al., 2012), It is therefore questionable to compare subduction zone scenarios typical for the Pacific plate to subduction scenarios of the Piemont Ligurian ocean.

\section{CONCLUSION}

The (U)HP units of the Dora-Maira, Monte Rosa, Gran Paradiso, Adula/Cima Lunga nappes and of the Zermatt-Saas Zone have the following common characteristics: (i) peak pressures are recorded in minor volumes of the corresponding tectonic units; (ii) the oldest deformation postdating the peak-pressure denotes top-to-the-foreland kinematics; (iii) (U)HP rocks occur within coherent imbricate thrust sheets which show substantial pressure jumps; and (iv) fast decompression (< 2 Ma) from (U)HP (4 to $>1.5 \mathrm{GPa}$ ) to greenschist- or amphibolite-facies $(\sim 1$ $\mathrm{GPa}$ ) metamorphic conditions. Furthermore, (v) the observed imbricate fragments of the AlpineTethyan basins suggest that the PCW Alps resulted from the convergence of hyperextended margins and basins with exhumed serpentinized subcontinental mantle rather than from the closure of oceans with newly formed oceanic crust and mantle (Penrose-type).

Each of the above characteristics disagrees with fundamental features of lithostatic exhumation models for the PCW Alps: (i) The return flow in a subduction channel should exhume volumes of UHP rocks that are one to two orders of magnitude larger than the UHP volumes reported. Therefore, this exhumation mechanism seems unsuitable for the PCW Alps. Stokes flow could rapidly exhume small (U)HP rock units if surrounding rocks would have low viscosity $\left(10^{18}-10^{19} \mathrm{Pas}\right)$ and high density $\left(>3180 \mathrm{kgm}^{-3}\right)$. However, such surrounding rocks have not been reported yet in the PCW Alps. (ii) The exhumation of (U)HP units in a subduction channel or by extension requires prominent top-to-the-hinterland normal faults in their hanging wall which are active during (U)HP conditions. (iii) Numerical simulations of exhumation with stresses close to lithostatic pressure did not generate yet a coherent and imbricate nappe stack with characteristic jumps in peak pressure and temperature. (iv) An increase of erosion rate due to a fast exhumation is not observed. (v) A lithosphere with hyperextended margins and basins with exhumed serpentinized subcontinental mantle is less negatively buoyant than a newly formed Penrose-type oceanic lithosphere. Therefore, the forces due to slab pull and rollback may have been significantly less as commonly assumed. 
An orogenic wedge, which is formed during the convergence of hyperextended margins with exhumed serpentinized subcontinental mantle and involves dynamic stresses deviating from the lithostatic pressure, could explain (i) the local character of (U)HP rocks, (ii) the dominant regional top-to-the-foreland (U)HP kinematics and the significant jumps in peak pressure and temperature between and within the nappes, (iii) the imbricate and coherent nappe stack, and (iv) the fast decompression ( $<\sim 2 \mathrm{Ma}$ ). Quantifying the magnitude of dynamic stresses during orogeny and understanding their impact on metamorphic reactions are the main challenges for the dynamic orogenic wedge model.

\section{ACKNOWLEDGEMENTS:}

We are grateful to the reviewers G. Mohn and R. Compagnoni for the contributions and comments that helped to improve this paper. We thank Jean-Pierre Burg, Peter Nievergelt, Suzanne Picazo and Thibault Duretz which helped to clarify text, concepts and processes and Alba Zappone for the density measurements of the Dora-Maira and Zermatt-Saas rocks. E.M. and J.V. would like to acknowledge the ERC starting grant (335577) for financial support. This work was supported by the University of Lausanne.

\section{REFERENCES}

Agard, P., Yamato, P., Jolivet, L. \& Burov, E., 2009. Exhumation of oceanic blueschists and eclogites in subduction zones: Timing and mechanisms. Earth-Science Reviews, 92, 53-79.

Amato, J. M., Johnson, C. M., Baumgartner, L. P. \& Beard, B. L., 1999. Rapid exhumation of the Zermatt-Saas ophiolite deduced from high-precision Sm$\mathrm{Nd}$ and $\mathrm{Rb}-\mathrm{Sr}$ geochronology. Earth and Planetary Science Letters, 171, 425438.

Angiboust, S. \& Agard, P., 2010. Initial water budget: The key to detaching large volumes of eclogitized oceanic crust along the subduction channel? Lithos, 120, 453-474.

Angiboust, S., Agard, P., Jolivet, L. \& Beyssac, O., 2009. The Zermatt-Saas ophiolite: the largest $(60-\mathrm{km}$ wide) and deepest (c.70-80 km) continuous slice of oceanic lithosphere detached from a subduction zone? Terra Nova, 21, 171180.

Anonymous, 1972. Penrose field conference on ophiolites. Geotimes, 17, 24-25.

Argand, E., 1916. Sur l'arc des Alpes occidentales. G. Bridel.

Avigad, D., Chopin, C. \& Le Bayon, R., 2003. Thrusting and extension in the southern Dora-Maira ultra-high-pressure massif (Western Alps): View from below the coesite-bearing unit. The Journal of geology, 111, 57-70.

Barnicoat, A. C. \& Fry, N., 1986. High-pressure metamorphism of the Zermatt-Saas ophiolite zone, Switzerland. Journal of the Geological Society, 143, 607-618.

Baudin, T. \& Marquer, D., 1993. Metamorphism and deformation in the Tambo nappe (Swiss central Alps)-Evolution of the phengite substitution during Alpine deformation. Schweizerische Mineralogische und Petrographische Mitteilungen, 73, 285-299.

Bearth, P., 1952. Geologie und petrographie des Monte Rosa. Kümmerly \& Frey.

Bearth, P., 1959. Über Eklogite, Glaukophanschiefer und metamorphe Pillowlaven. Schweizerische Mineralogische Und Petrographische Mitteilungen, 39, 267286. 
Bearth, P., 1962. Versuch einer Gliederung alpinmetamorpher Serien der Westalpen. Schweizerische mineralogische und petrographische Mitteilungen, 42, 127137.

Bearth, P., 1967. Die Ophiolithe der Zone von Zermatt-Saas Fee. Kümmerly \& Frey.

Becker, H., 1993. Garnet peridotite and eclogite Sm-Nd mineral ages from the Lepontine dome (Swiss Alps): New evidence for Eocene high-pressure metamorphism in the central Alps. Geology, 21, 599-602.

Beltrando, M., Lister, G. S., Rosenbaum, G., Richards, S. \& Forster, M. A., 2010. Recognizing episodic lithospheric thinning along a convergent plate margin: The example of the Early Oligocene Alps. Earth-Science Reviews, 103, 81-98.

Berger, A. \& Bousquet, R., 2008. Subduction-related metamorphism in the Alps: review of isotopic ages based on petrology and their geodynamic consequences. Geological Society, London, Special Publications, 298, 117144.

Bergomi, M. A., Zanchetta, S. \& Tunesi, A., 2014. The Tertiary dike magmatism in the Southern Alps: geochronological data and geodynamic significance. International Journal of Earth Sciences, 104, 449-473.

Borghi, A., Compagnoni, R. \& Sandrone, R., 1996. Composite PT paths in the internal Penninic massifs of the western Alps: petrological constraints to their thermomechanical evolution. Eclogae Geologicae Helvetiae, 89, 345-367.

Brown, M., 2014. The contribution of metamorphic petrology to understanding lithosphere evolution and geodynamics. Geoscience Frontiers, 5, 553-569.

Bucher, K., 2005. Blueschists, eclogites, and decompression assemblages of the Zermatt-Saas ophiolite: High-pressure metamorphism of subducted Tethys lithosphere. American Mineralogist, 90, 821-835.

Buchs, N., 2013. Géochimie, métamorphisme et structures dans la Zone de Zermatt-Saas Fee - Du Pfulwe au Strahlhorn, Zermatt, Université de Lausanne, Lausanne.

Bürgmann, R. \& Dresen, G., 2008. Rheology of the Lower Crust and Upper Mantle: Evidence from Rock Mechanics, Geodesy, and Field Observations. Annual Review of Earth and Planetary Sciences, 36, 531-567.

Burov, E., Francois, T., Yamato, P. \& Wolf, S., 2014. Mechanisms of continental subduction and exhumation of HP and UHP rocks. Gondwana Research, 25, 464-493.

Burov, E., Jolivet, L., Le Pourhiet, L. \& Poliakov, A., 2001. A thermomechanical model of exhumation of high pressure (HP) and ultra-high pressure (UHP) metamorphic rocks in Alpine-type collision belts. Tectonophysics, 342, 113136.

Butler, J. P., Beaumont, C. \& Jamieson, R. A., 2013. The Alps 1: A working geodynamic model for burial and exhumation of (ultra)high-pressure rocks in Alpine-type orogens. Earth and Planetary Science Letters, 377-378, 114131.

Butler, J. P., Beaumont, C. \& Jamieson, R. A., 2014. The Alps 2: Controls on crustal subduction and (ultra)high-pressure rock exhumation in Alpine-type orogens. Journal of Geophysical Research-Solid Earth, 119, 5987-6022.

Cartwright, I. \& Barnicoat, A. C., 1999. Stable isotope geochemistry of Alpine ophiolites: a window to ocean-floor hydrothermal alteration and constraints on fluid-rock interaction during high-pressure metamorphism. International Journal of Earth Sciences, 88, 219-235. 
Castelli, D., Rolfo, F., Groppo, C. \& Compagnoni, R., 2007. Impure marbles from the UHP Brossasco-Isasca Unit (Dora-Maira Massif, western Alps): evidence for Alpine equilibration in the diamond stability field and evaluation of the X(CO2) fluid evolution. Journal of Metamorphic Geology, 25, 587-603.

Cavargna-Sani, M., Epard, J.-L. \& Steck, A., 2014. Structure, geometry and kinematics of the northern Adula nappe (Central Alps). Swiss Journal of Geosciences, 107, 135-156.

Chinner, G. A. \& Dixon, J. E., 1973. Some High-pressure Parageneses of the Allalin Gabbro, Valais, Switzerland. Journal of Petrology, 14, 185-202.

Chopin, C., 1984. Coesite and Pure Pyrope in High-Grade Blueschists of the Western Alps - a 1st Record and Some Consequences. Contributions to Mineralogy and Petrology, 86, 107-118.

Chopin, C., Henry, C. \& Michard, A., 1991. Geology and petrology of the coesitebearing terrain, Dora Maira massif, Western Alps. European Journal of Mineralogy, 3, 263-291.

Chopin, C. \& Monié, P., 1984. A unique magnesiochloritoid-bearing, high-pressure assemblage from the Monte Rosa, Western Alps: petrologic and 40Ar-39Ar radiometric study. Contributions to Mineralogy and Petrology, 87, 388-398.

Clark, S. P., 1961. A redetermination of equilibrium relations between kyanite and sillimanite. American Journal of Science, 259, 641-650.

Cloos, M., 1993. Lithospheric Buoyancy and Collisional Orogenesis - Subduction of Oceanic Plateaus, Continental Margins, Island Arcs, Spreading Ridges, and Seamounts. Geological Society of America Bulletin, 105, 715-737.

Compagnoni, R., 2003. HP metamorphic belt of the western Alps. Episodes, 26, 200204.

Compagnoni, R. \& Hirajima, T., 2001. Superzoned garnets in the coesite-bearing Brossasco-Isasca Unit, Dora-Maira massif, Western Alps, and the origin of the whiteschists. Lithos, 57, 219-236.

Compagnoni, R. \& Rolfo, F., 2003. UHPM units in the Western Alps. Eötvös University Press, Budapest, Hungary.

Compagnoni, R., Rolfo, F., Groppo, C., Hirajima, T. \& Turello, R., 2012. Geological map of the ultra-high pressure Brossasco-Isasca unit (Western Alps, Italy). Journal of Maps, 8, 465-472.

Dal Piaz, G., 1971. Nuovi ritrovamenti di cianite alpina nel cristallino antico del Monte Rosa. Rendiconti della Società Italiana di Mineralogia e Petrologia, 27, 437-477.

Dal Piaz, G., Lombardo, B. \& Gosso, G., 1983. Metamorphic evolution of the Mt. Emilius klippe, Dent Blanche nappe, western Alps. American Journal of Science, 283, 438-458.

Dal Piaz, G. V. \& Gatto, G. O., 1963. Considerazioni geologico-petrografiche sul versante meridionale del Monte Rosa. Accademia Nazionale dei Lincei, Rendiconti della Classe di Scienze Fisiche, Matematiche e Naturali.

Dal Piaz, G. V. \& Lombardo, B., 1986. Early Alpine eclogite metamorphism in the Penninic Monte Rosa-Gran Paradiso basement nappes of the northwestern Alps. Geological Society of America Memoirs, 164, 249-266.

Dale, J. \& Holland, T., 2003. Geothermobarometry, P-T paths and metamorphic field gradients of high-pressure rocks from the Adula Nappe, Central Alps. Journal of Metamorphic Geology, 21, 813-829. 
de Meyer, C. M. C., Baumgartner, L. P., Beard, B. L. \& Johnson, C. M., 2014. Rb-Sr ages from phengite inclusions in garnets from high pressure rocks of the Swiss Western Alps. Earth and Planetary Science Letters, 395, 205-216.

Debelmas, J. \& Lemoine, M., 1970. The western Alps: palaeogeography and structure. Earth-Science Reviews, 6, 221-256.

Duchêne, S., Blichert-Toft, J., Luais, B., Télouk, P., Lardeaux, J. \& Albarede, F., 1997. The Lu-Hf dating of garnets and the ages of the Alpine high-pressure metamorphism. Nature, 637, 20-29.

Engi, M., Berger, A. \& Roselle, G. T., 2001a. Role of the tectonic accretion channel in collisional orogeny. Geology, 29, 1143-1146.

Engi, M., Scherrer, N. \& Burri, T., 2001b. Metamorphic evolution of pelitic rocks of the Monte Rosa nappe: Constraints from petrology and single grain monazite age data. Schweizerische mineralogische und petrographische Mitteilungen, 81, 305-328.

England, P. \& Holland, T., 1979. Archimedes and the Tauern eclogites: the role of buoyancy in the preservation of exotic eclogite blocks. Earth and Planetary Science Letters, 44, 287-294.

Ernst, W. \& Dal Piaz, G., 1978. Mineral parageneses of eclogitic rocks and related mafic schists of the Piemonte ophiolite nappe, Breuil-St. Jacques area, Italian Western Alps. Am. Mineral, 63, 621-640.

Evans, B., Trommsdorff, V. \& Richter, W., 1979. Petrology of an eclogitemetarodingite suite at Cima di Gagnone, Ticino, Switzerland. Am. Mineral, 64, $15-31$.

Ferrando, S., Frezzotti, M. L., Petrelli, M. \& Compagnoni, R., 2009. Metasomatism of continental crust during subduction: the UHP whiteschists from the Southern Dora-Maira Massif (Italian Western Alps). Journal of Metamorphic Geology, 27, 739-756.

Ford, M., Duchêne, S., Gasquet, D. \& Vanderhaeghe, O., 2006. Two-phase orogenic convergence in the external and internal SW Alps. Journal of the Geological Society, 163, 815-826.

Frezzotti, M. L., Selverstone, J., Sharp, Z. D. \& Compagnoni, R., 2011. Carbonate dissolution during subduction revealed by diamond-bearing rocks from the Alps. Nature Geoscience, 4, 703-706.

Froitzheim, N., Pleuger, J., Roller, S. \& Nagel, T., 2003. Exhumation of high-and ultrahigh-pressure metamorphic rocks by slab extraction. Geology, 31, 925928.

Gabudianu Radulescu, I., Rubatto, D., Gregory, C. \& Compagnoni, R., 2009. The age of HP metamorphism in the Gran Paradiso Massif, Western Alps: A petrological and geochronological study of "silvery micaschists". Lithos, 110, 95-108.

Ganguin, J., 1988. Contribution à la caracterisation du métamorphisme polyphase de la zone de Zermatt-Saas Fee (Alpes Valaisannes), ETH Zürich, n 8731, Zürich.

Gasco, I., Borghi, A. \& Gattiglio, M., 2010. Metamorphic evolution of the Gran Paradiso Massif: A case study of an eclogitic metagabbro and a polymetamorphic glaucophane-garnet micaschist. Lithos, 115, 101-120.

Gasco, I., Borghi, A. \& Gattiglio, M., 2011. P-T Alpine metamorphic evolution of the Monte Rosa nappe along the Piedmont Zone boundary (Gressoney Valley, NW Italy). Lithos, 127, 336-353. 
Gerya, T. V., Perchuk, L. L. \& Burg, J. P., 2008. Transient hot channels: Perpetrating and regurgitating ultrahigh-pressure, high-temperature crust-mantle associations in collision belts. Lithos, 103, 236-256.

Groppo, C., Beltrando, M. \& Compagnoni, R., 2009. The $P-T$ path of the ultra-high pressure Lago Di Cignana and adjoining high-pressure meta-ophiolitic units: insights into the evolution of the subducting Tethyan slab. Journal of Metamorphic Geology, 27, 207-231.

Handy, M. R., M. Schmid, S., Bousquet, R., Kissling, E. \& Bernoulli, D., 2010. Reconciling plate-tectonic reconstructions of Alpine Tethys with the geological-geophysical record of spreading and subduction in the Alps. EarthScience Reviews, 102, 121-158.

Heinrich, C. A., 1982. Kyanite-eclogite to amphibolite fades evolution of hydrous mafic and pelitic rocks, Adula nappe, Central Alps. Contributions to Mineralogy and Petrology, 81, 30-38.

Heinrich, C. A., 1986. Eclogite facies regional metamorphism of hydrous mafic rocks in the Central Alpine Adula Nappe. Journal of Petrology, 27, 123-154.

Henry, C., Michard, A. \& Chopin, C., 1993. Geometry and Structural Evolution of Ultra-High-Pressure and High-Pressure Rocks from the Dora-Maira Massif, Western Alps, Italy. Journal of Structural Geology, 15, 965-981.

Hermann, J., 2003. Experimental evidence for diamond-facies metamorphism in the Dora-Maira massif. Lithos, 70, 163-182.

Herwartz, D., Nagel, T. J., Münker, C., Scherer, E. E. \& Froitzheim, N., 2011. Tracing two orogenic cycles in one eclogite sample by Lu-Hf garnet chronometry. Nature Geoscience, 4, 178-183.

Jolivet, L., Faccenna, C., Goffe, B., Burov, E. \& Agard, P., 2003. Subduction tectonics and exhumation of high-pressure metamorphic rocks in the Mediterranean orogens. American Journal of Science, 303, 353-409.

Kapferer, N., Mercolli, I., Berger, A., Ovtcharova, M. \& Fügenschuh, B., 2012. Dating emplacement and evolution of the orogenic magmatism in the internal Western Alps: 2. The Biella Volcanic Suite. Swiss Journal of Geosciences, 105 67-84.

Karato, S.-i., 2010. Rheology of the Earth's mantle: A historical review. Gondwana Research, 18, 17-45.

Lagabrielle, Y., Polino, R., Auzende, J., Blanchet, R., Caby, R., Fudral, S., Lemoine, M., Mevel, C., Ohnenstetter, M. \& Robert, D., 1984. Les témoins d'une tectonique intra-océanique dans le domaine téthysien: analyse des rapports entre les ophiolites et leurs couvertures métasédimentaires dans la zone piémontaise des Alpes franco-italiennes. Ofioliti, 9, 67-88.

Lagabrielle, Y., Vitale Brovarone, A. \& Ildefonse, B., 2015. Fossil oceanic core complexes recognized in the blueschist metaophiolites of Western Alps and Corsica. Earth-Science Reviews, 141, 1-26.

Lapen, T. J., Johnson, C. M., Baumgartner, L. P., Dal Piaz, G. V., Skora, S. \& Beard, B. L., 2007. Coupling of oceanic and continental crust during Eocene eclogitefacies metamorphism: evidence from the Monte Rosa nappe, western Alps. Contributions to Mineralogy and Petrology, 153, 139-157.

Lapen, T. J., Johnson, C. M., Baumgartner, L. P., Mahlen, N. J., Beard, B. L. \& Amato, J. M., 2003. Burial rates during prograde metamorphism of an ultra-highpressure terrane: an example from Lago di Cignana, western Alps, Italy. Earth and Planetary Science Letters, 215, 57-72. 
Le Bayon, B., Pitra, P., Ballevre, M. \& Bohn, M., 2006a. Reconstructing P-T paths during continental collision using multi-stage garnet (Gran Paradiso nappe, Western Alps). Journal of Metamorphic Geology, 24, 477-496.

Le Bayon, R., de Capitani, C., Chopin, C. \& Frey, M., 2000. Modeling of the sequential evolution of whiteschist assemblages: HP in the Monte Rosa (western Alps). Beiheft zu European journal of mineralogy, 12, 111.

Le Bayon, R., de Capitani, C. \& Frey, M., 2006b. Modelling phase-assemblage diagrams for magnesian metapelites in the system $\mathrm{K}_{2} \mathrm{O}-\mathrm{FeO}-\mathrm{MgO}-\mathrm{Al}_{2} \mathrm{O}_{3}-\mathrm{SiO}_{2}-$ H2O: geodynamic consequences for the Monte Rosa nappe, western Alps. Contributions to Mineralogy and Petrology, 151, 395-412.

Lemoine, M., Tricart, P. \& Boillot, G., 1987. Ultramafic and gabbroic ocean floor of the Ligurian Tethys (Alps, Corsica, Apennines): In search of a genetic imodel. Geology, 15, 622-625.

Löw, S., 1987. Die tektono-metamorphe Entwicklung der Nördlichen Adula-Decke: Zentralalpen, Schweiz. Schweizerische Geologische Kommission.

Mahlen, N. J., Johnson, C. M., Baumgartner, L. P. \& Beard, B. L., 2005. Provenance of Jurassic Tethyan sediments in the HP/UHP Zermatt-Saas ophiolite, western Alps. Geological Society of America Bulletin, 117, 530.

Mancktelow, N. S., 1993. Tectonic Overpressure in Competent Mafic Layers and the Development of Isolated Eclogites. Journal of Metamorphic Geology, 11, 801812.

Mancktelow, N. S., 2008. Tectonic pressure: theoretical concepts and modelled examples. Lithos, 103, 149-177.

Matsumoto, N. \& Hirajima, T., 2000. Garnet in pelitic schists from a quartz-eclogite unit of the southern Dora-Maira massif, Western Alps. Schweizerische mineralogische und petrographische Mitteilungen, 80, 53-62.

Meffan-Main, S., Cliff, R., Barnicoat, A., Lombardo, B. \& Compagnoni, R., 2004. A Tertiary age for Alpine high-pressure metamorphism in the Gran Paradiso massif, Western Alps: A Rb-Sr microsampling study. Journal of Metamorphic Geology, 22, 267-281.

Meyre, C., De Capitani, C., Zack, T. \& Frey, M., 1999. Petrology of high-pressure metapelites from the Adula nappe (Central Alps, Switzerland). Journal of Petrology, 40, 199-213.

Meyre, C. \& Puschnig, A., 1993. High-pressure metamorphism and deformation at Trescolmen, Adula nappe, Central Alps. Schweizerische Mineralogische und Petrographische Mitteilungen, 73, 277-283.

Michard, A., Chopin, C. \& Henry, C., 1993. Compression versus extension in the exhumation of the Dora-Maira coesite-bearing unit, Western Alps, Italy. Tectonophysics, 221, 173-193.

Minshull, T., Muller, M., Robinson, C., White, R. \& Bickle, M., 1998. Is the oceanic Moho a serpentinization front? Geological Society, London, Special Publications, 148, 71-80.

Mohn, G., Manatschal, G., Beltrando, M. \& Haupert, I., 2014. The role of rift-inherited hyper-extension in Alpine-type orogens. Terra Nova, 26, 347-353.

Mohn, G., Manatschal, G., Muntener, O., Beltrando, M. \& Masini, E., 2010. Unravelling the interaction between tectonic and sedimentary processes during lithospheric thinning in the Alpine Tethys margins. International Journal of Earth Sciences, 99, S75-S101. 
Moulas, E., Burg, J.-P. \& Podladchikov, Y., 2014. Stress field associated with elliptical inclusions in a deforming matrix: Mathematical model and implications for tectonic overpressure in the lithosphere. Tectonophysics, 631, 37-49.

Moulas, E., Podladchikov, Y. Y., Aranovich, L. Y. \& Kostopoulos, D., 2013. The problem of depth in geology: When pressure does not translate into depth. Petrology, 21, 527-538.

Müntener, O., Manatschal, G., Desmurs, L. \& Pettke, T., 2010. Plagioclase peridotites in ocean-continent transitions: refertilized mantle domains generated by melt stagnation in the shallow mantle lithosphere. Journal of Petrology, 51, 255294.

Müntener, O., Pettke, T., Desmurs, L., Meier, M. \& Schaltegger, U., 2004. Refertilization of mantle peridotite in embryonic ocean basins: trace element and $\mathrm{Nd}$ isotopic evidence and implications for crust-mantle relationships. Earth and Planetary Science Letters, 221, 293-308.

Muntener, O. \& Piccardo, G. B., 2003. Melt migration in ophiolitic peridotites: the message from Alpine-Apennine peridotites and implications for embryonic ocean basins. Special Publication-Geological society of London, 218, 69-90.

Nagel, T., de Capitani, C., Frey, M., Froitzheim, N., Stünitz, H. \& Schmid, S. M., 2002. Structural and metamorphic evolution during rapid exhumation in the Lepontine dome (southern Simano and Adula nappes, Central Alps, Switzerland). Eclogae Geologicae Helveticae, 95, 301-321.

Nicolas, A., Boudier, F. \& Ildefonse, B., 1996. Variable crustal thickness in the Oman ophiolite: implication for oceanic crust. Journal of Geophysical Research: Solid Earth (1978-2012), 101, 17941-17950.

Oberhänsli, R., 1982. The PT history of some pillow lavas from Zermatt. Ofioliti, 7, 3.

Oberhänsli, R., Hunziker, J., Martinotti, G. \& Stern, W., 1985. Geochemistry, geochronology and petrology of Monte Mucrone: an example of Eo-Alpine eclogitization of Permian granitoids in the Sesia-Lanzo Zone, Western Alps, Italy. Chemical Geology: Isotope Geoscience section, 52, 165-184.

Pawlig, S. \& Baumgartner, L. P., 2001. Geochemistry of a talc-kyanite-chloritoid shear zone within the Monte Rosa granite, Val d'Ayas, Italy. Schweizerische mineralogische und petrographische Mitteilungen, 81, 329-346.

Petrini, K. \& Podladchikov, Y., 2000. Lithospheric pressure-depth relationship in compressive regions of thickened crust. Journal of Metamorphic Geology, 18, 67-77.

Pfeifer, H. R., Colombi, A. \& Ganguin, J., 1989. Zermatt-Saas and Antrona Zone - a Petrographic and Geochemical Comparison of Polyphase Metamorphic Ophiolites of the West-Central Alps. Schweizerische mineralogische und petrographische Mitteilungen, 69, 217-236.

Platt, J. P., 1986. Dynamics of Orogenic Wedges and the Uplift of High-Pressure Metamorphic Rocks. Geological Society of America Bulletin, 97, 1037-1053.

Pleuger, J., Froitzheim, N. \& Jansen, E., 2005. Folded continental and oceanic nappes on the southern side of Monte Rosa (western Alps, Italy): Anatomy of a double collision suture. Tectonics, 24, TC4013.

Pleuger, J., Hundenborn, R., Kremer, K., Babinka, S., Kurz, W., Jansen, E. \& Froitzheim, N., 2003. Structural evolution of Adula nappe, Misox zone, and Tambo nappe in the San Bernardino area: Constraints for the exhumation of the Adula eclogites. Mitteilungen der Österreichischen Geologischen Gesellschaft, 94, 99-122. 
Pleuger, J. \& Podladchikov, Y. Y., 2014. A purely structural restoration of the NFP20East cross section and potential tectonic overpressure in the Adula nappe (central Alps). Tectonics, 33, 656-685.

Pleuger, J., Roller, S., Walter, J. M., Jansen, E. \& Froitzheim, N., 2007. Structural evolution of the contact between two Penninic nappes (Zermatt-Saas zone and Combin zone, Western Alps) and implications for the exhumation mechanism and palaeogeography. International Journal of Earth Sciences, 96, 229-252.

Reddy, S. M., Wheeler, J. \& Cliff, R. A., 1999. The geometry and timing of orogenic extension: an example from the Western Italian Alps. Journal of Metamorphic Geology, 17, 573-589.

Regis, D., Rubatto, D., Darling, J., Cenki-Tok, B., Zucali, M. \& Engi, M., 2014. Multiple Metamorphic Stages within an Eclogite-facies Terrane (Sesia Zone, Western Alps) Revealed by Th-U-Pb Petrochronology. Journal of Petrology, 55, 14291456.

Reinecke, T., 1998. Prograde high- to ultrahigh-pressure metamorphism and exhumation of oceanic sediments at Lago di Cignana, Zermatt-Saas Zone, western Alps. Lithos, 42, 147-189.

Rosenbaum, G. \& Lister, G. S., 2005. The Western Alps from the Jurassic to Oligocene: spatio-temporal constraints and evolutionary reconstructions. Earth-Science Reviews, 69, 281-306.

Rosenbaum, G., Menegon, L., Glodny, J., Vasconcelos, P., Ring, U., Massironi, M., Thiede, D. \& Nasipuri, P., 2012. Dating deformation in the Gran Paradiso Massif (NW Italian Alps): Implications for the exhumation of high-pressure rocks in a collisional belt. Lithos, 144-145, 130-144.

Rubatto, D., Gebauer, D. \& Fanning, M., 1998. Jurassic formation and Eocene subduction of the Zermatt-Saas-Fee ophiolites: implications for the geodynamic evolution of the Central and Western Alps. Contributions to Mineralogy and Petrology, 132, 269-287.

Rubatto, D. \& Hermann, J., 2001. Exhumation as fast as subduction? Geology, 29, 36.

Rutti, R., 2001. Tectono-metamorphic evolution of the Simano-Adula nappe boundary, Central Alps, Switzerland. Schweizerische mineralogische und petrographische Mitteilungen, 81, 115-129.

Rybacki, E. \& Dresen, G., 2000. Dislocation and diffusion creep of synthetic anorthite aggregates. Journal of Geophysical Research, 105, 26017.

Sandmann, S., Nagel, T. J., Herwartz, D., Fonseca, R. O. C., Kurzawski, R. M., Münker, C. \& Froitzheim, N., 2014. Lu-Hf garnet systematics of a polymetamorphic basement unit: new evidence for coherent exhumation of the Adula Nappe (Central Alps) from eclogite-facies conditions. Contributions to Mineralogy and Petrology, 168.

Schaltegger, U., Desmurs, L., Manatschal, G., Müntener, O., Meier, M., Frank, M. \& Bernoulli, D., 2002. The transition from rifting to sea-floor spreading within a magma-poor rifted margin: field and isotopic constraints. Terra Nova, 14, 156-162.

Schertl, H.-P., Schreyer, W. \& Chopin, C., 1991. The pyrope-coesite rocks and their country rocks at Parigi, Dora Maira Massif, Western Alps: detailed petrography, mineral chemistry and PT-path. Contributions to Mineralogy and Petrology, 108, 1-21. 
Schmalholz, S. M. \& Duretz, T., 2015. Shear zone and nappe formation by thermal softening, related stress and temperature evolution, and application to the Alps. Journal of Metamorphic Geologyn/a-n/a.

Schmalholz, S. M., Duretz, T., Schenker, F. L. \& Podladchikov, Y. Y., 2014. Kinematics and dynamics of tectonic nappes: 2-D numerical modelling and implications for high and ultra-high pressure tectonism in the Western Alps. Tectonophysics, 631, 160-175.

Schmalholz, S. M. \& Podladchikov, Y. Y., 2013. Tectonic overpressure in weak crustalscale shear zones and implications for the exhumation of high-pressure rocks. Geophysical Research Letters, 40, 1984-1988.

Schmid, D. W. \& Podladchikov, Y. Y., 2003. Analytical solutions for deformable elliptical inclusions in general shear. Geophysical Journal International, 155, 269-288.

Schmid, S. M., Fügenschuh, B., Kissling, E. \& Schuster, R., 2004. Tectonic map and overall architecture of the Alpine orogen. Eclogae Geologicae Helvetiae, 97, 93-117.

Schmid, S. M., Pfiffner, O., Froitzheim, N., Schönborn, G. \& Kissling, E., 1996. Geophysical-geological transect and tectonic evolution of the Swiss-Italian Alps. Tectonics, 15, 1036-1064.

Schreyer, W., 1995. Ultradeep metamorphic rocks: The retrospective viewpoint. Journal of Geophysical Research: Solid Earth (1978-2012), 100, 8353-8366.

Sciunnach, D. \& Borsato, A., 1994. Plagioclase-arenites in the Molveno Lake area (Trento): record of an Eocene volcanic arc. Studi Trentini di Scienze Naturali (Trento).

Sinton, J. M. \& Detrick, R. S., 1992. Midocean Ridge Magma Chambers. Journal of Geophysical Research-Solid Earth, 97, 197-216.

Sizova, E., Gerya, T. \& Brown, M., 2014. Contrasting styles of Phanerozoic and Precambrian continental collision. Gondwana Research, 25, 522-545.

Skora, S., Baumgartner, L. P., Mahlen, N. J., Johnson, C. M., Pilet, S. \& Hellebrand, E., 2006. Diffusion-limited REE uptake by eclogite garnets and its consequences for $\mathrm{Lu}-\mathrm{Hf}$ and $\mathrm{Sm}-\mathrm{Nd}$ geochronology. Contributions to Mineralogy and Petrology, 152, 703-720.

Skora, S., Baumgartner, L. P., Mahlen, N. J., Lapen, T. J., Johnson, C. M. \& Bussy, F., 2008. Estimation of a maximum Lu diffusion rate in a natural eclogite garnet. Swiss Journal of Geosciences, 101, 637-650.

Skora, S., Lapen, T. J., Baumgartner, L. P., Johnson, C. M., Hellebrand, E. \& Mahlen, N. J., 2009. The duration of prograde garnet crystallization in the UHP eclogites at Lago di Cignana, Italy. Earth and Planetary Science Letters, 287, 402-411.

Spear, F. S., 1995. Metamorphic Phase Equilibria and Pressure-Temperature-Time Paths, Washington, D.C.

Spiegel, C., Kuhlemann, J., Dunkl, I., Frisch, W., Von Eynatten, H. \& Balogh, K., 2000. The erosion history of the Central Alps: evidence from zircon fission track data of the foreland basin sediments. Terra Nova, 12, 163-170.

Stampfli, G., Mosar, J., Marquer, D., Marchant, R., Baudin, T. \& Borel, G., 1998. Subduction and obduction processes in the Swiss Alps. Tectonophysics, 296, 159-204.

Steck, A., Bigioggero, B., Dal Piaz, G. V., Escher, A., Martinotti, G. \& Masson, H., 2001. Carte tectonique des Alpes de Suisse occidentale et des régions avoisinantes 1:100'000 (ed Géologie, O. f. S.-E.), Berne. 
Steck, A. \& Hunziker, J., 1994. The Tertiary structural and thermal evolution of the Central Alps-compressional and extensional structures in an orogenic belt. Tectonophysics, 238, 229-254.

Stöckhert, B. \& Gerya, T. V., 2005. Pre-collisional high pressure metamorphism and nappe tectonics at active continental margins: a numerical simulation. Terra Nova, 17, 102-110.

Tajčmanová, L., Podladchikov, Y., Powell, R., Moulas, E., Vrijmoed, J. C. \& Connolly, J. A. D., 2014. Grain-scale pressure variations and chemical equilibrium in highgrade metamorphic rocks. Journal of Metamorphic Geology, 32, 195-207.

Tilton, G., Schreyer, W. \& Schertl, H.-P., 1991. Pb- Sr- Nd isotopic behavior of deeply subducted crustal rocks from the Dora Maira Massif, Western Alps, Italy-II: what is the age of the ultrahigh-pressure metamorphism? Contributions to Mineralogy and Petrology, 108, 22-33.

Tricart, P., 1984. From passive margin to continental collision; a tectonic scenario for the Western Alps. American Journal of Science, 284, 97-120.

Trümpy, R., 1973. The timing of orogenic events in the Central Alps. Gravity and tectonics. Wiley, New York229-251.

Trümpy, R. \& Homewood, P., 1980. Geology of Switzerland: a guide-book. Wepf and Company.

Vialon, P., 1966. Étude géologique du Massif Cristallin Dora-Maira, Alpes Cottiennes Internes - Italie, Faculté des Sciences de l'Université de Grenoble.

Vissers, R. L. M., van Hinsbergen, D. J. J., Meijer, P. T. \& Piccardo, G. B., 2013. Kinematics of Jurassic ultra-slow spreading in the Piemonte Ligurian ocean. Earth and Planetary Science Letters, 380, 138-150.

Von Blanckenburg, F. \& Davies, J. H., 1995. Slab Breakoff - a Model for Syncollisional Magmatism and Tectonics in the Alps. Tectonics, 14, 120-131.

von Blanckenburg, F., Früh-Green, G., Diethelm, K. \& Stille, P., 1992. Nd-, Sr-, Oisotopic and chemical evidence for a two-stage contamination history of mantle magma in the Central-Alpine Bergell intrusion. Contributions to Mineralogy and Petrology, 110, 33-45.

Wheeler, J., 1991. Structural Evolution of a Subducted Continental Sliver - the Northern Dora Maira Massif, Italian Alps. Journal of the Geological Society, 148, 1101-1113.

Yamato, P., Burov, E., Agard, P., Le Pourhiet, L. \& Jolivet, L., 2008. HP-UHP exhumation during slow continental subduction: Self-consistent thermodynamically and thermomechanically coupled model with application to the Western Alps. Earth and Planetary Science Letters, 271, 63-74.

\section{Figures caption:}

Fig. 1: Examples of subduction dynamics models proposed for the PCW Alps.

Fig. 2: Examples of possible pressure variations at different scales in the PCW Alps with sketch (left) and pressure - temperature estimates (right). (a) Garnet in a garnet-phengite-quartz-schist of the Lago di Cignana (Reinecke, 1998) with inclusion, from core to rim, of quartz, coesite and quartz demonstrates local spatial pressure variation within the garnet at the time of coesite formation and that these variations are preserved during compression and decompression. (b) Mafic eclogitic boudin within the Adula-Cima Lunga gneisses without evidence of HP mineral assemblage (Evans et al., 1979; Heinrich, 1982). (c) White schist lens within the weakly deformed late-Variscan Monte Rosa granite cut by a chlorite-biotite-white mica shear zone 
(Pawlig \& Baumgartner, 2001). Peak metamorphic condition of the whiteschists according to Le Bayon et al.. (2000). (d) Geological section of the Dora-Maira (Compagnoni et al., 2012), with Brossasco-Isasca UHP unit included in the lower-grade San Schiaffredo and Rocca Solei units (references for metamorphic condition in the text).

Fig. 3: Tectonic map of the PCW Alps modified after Schmid et al., (2004) with location of the UHP units. References for the representative metamorphic P-peak conditions in the text.

Fig. 4: Geological map of the Brossasco-Isasca region of the Dora-Maira unit and according to Compagnoni et al. (2012) with profile modified after Avigad et al. (2003).

Fig. 5: Evidence for the coherency of the Zermatt-Saas zone (ZSZ). Undifferentiated ZSZ = metamafite, schiste Lustré and minor serpentinites, MR = Monte Rosa Nappe, SU = Stockhorn Unit, PU = Portjengrat Unit, SB = St. Bernard Nappe, and DB = Dent Blanche nappe. (a) Tectonic map of the Zermatt-Saas zone and surrounding units after Steck et al. (2001) showing a continuous serpentinite layer extending over ca. $25 \mathrm{~km}$. (b) Geological map through the ZermattSaas zone in the Täsch Valley according to Ganguin (1988) and Buchs (2013) documenting the layered nature of the Zermatt-Saas zone resulting in large shards of several kilometer length and with only a few 10's to 100's of meter thickness. (c) Geological profile through the Zermatt-Saas zone. (d) Layered Spitze Fluh Metagabbro parallel to the regional foliation that exhibits a tabular shape of $0.1 \times 7 \times 4 \mathrm{~km}$. Late faults locally displace the tectonized contacts. Independently on the scale of observation, the lithologies of the Zermatt-Saas zone form continuous layers which are atypical for a tectonic mélange in a subduction channel.

Fig. 6: Theoretical representation of the channel flow. Thickness of $10 \mathrm{~km}$ of the upward subduction channel according to equation (1) and confirmed by numerical models exhuming UHP rocks (e.g. Butler et al., 2013). Short axis of the lenses and rectangles correspond to true thicknesses of the Dora-Maira and Zermatt-Saas units. Note the considerable difference in areas (which has to be translated in volume in a cylindrical orogen) between the observed UHP terranes (BIU) and the theoretical UHP (light gray).

Fig. 7: Theoretical representation of the Stokes flow of a single block applied to the Dora-Maira unit and Zermatt-Saas zone. Short axis of the lenses and rectangles correspond to true thicknesses of these units. Most numerical models generate diapirs that penetrate into the upper plate.

Fig. 8: End-members of published rifting models of the Tethyan realm at approximately $110 \mathrm{Ma}$; timing chosen just before the beginning of convergence in the southern margin (Trümpy, 1973).

(a) Extended lithosphere that led to the formation of continuous oceanic crust modified after Stampfli et al.. (1998). (b) Extended lithosphere that led to the exhumation of subcontinental mantle, with limited amount of magmatism and extended serpentinization (hyperextended margin) after Mohn et al., (2014). (c) Fast-spreading oceanic lithosphere modified after Nicolas et al., (1996), (d) conceptual sketch of the thinning within an exhumed subcontinental mantle. Structural architecture of sepentinites, gabbros and basalts and refertilized mantle domains and dunite channels from Muntener \& Piccardo (2003) and Müntener et al. (2010), respectively. Note the significant lithological differences between (c) showing $\sim 6 \mathrm{~km}$ of mafic crust and (d) exhibiting $2-5 \mathrm{~km}$ of serpentinized mantle with minor gabbroic and basaltic sheets. The 
rheological behavior and buoyancy of these two types of oceanic lithosphere is expected to be consistently different during convergence.

\section{Table caption:}

Table 1: Estimation of bulk densities of the (U)HP Brossasco-Isasca and Zermatt Saas units. (1) Densities computed with perplex (see Supporting Information A). (2) Densities measured in the Rock Deformation Laboratory at ETH Zurich. Samples were heated $24 \mathrm{~h}$ in a oven at $110^{\circ} \mathrm{C}$ to remove adsorbed water. The weight of samples was measured with a precision of $0.001 \mathrm{~g}$ and their volume measured with the aid of a Helium stereo-pycnometer with a precision of 0.0001 $\mathrm{mm}^{3}$. (3) Areas of the Brossasco-Isasca and Zermatt-Saas zones estimated with profiles in Figs 4, 5c. Rock properties in the buoyancy-driven exhumation of the Brossasco-Isasca unit have been estimated with the densities computed with Perplex (1), due to greenschist facies metamorphic retrogression of the measured rocks (2) that decreased the densities after P-peak condition. In the case of the Zermatt-Saas zone, the geodynamic estimations were calculated with the measured densities (2), since the eclogite samples were affected by minor post-Peak retrogression. 
a) orogenic wedge

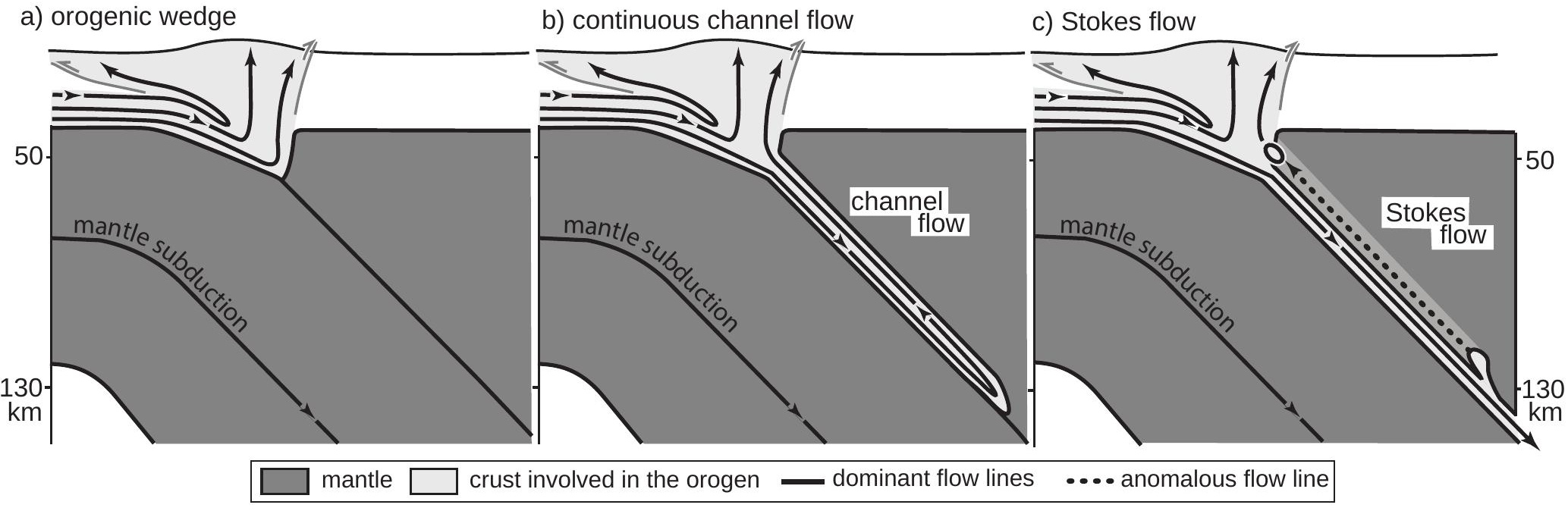

c) Stokes flow 
a) Lago di Cignana: sample Cig90/25

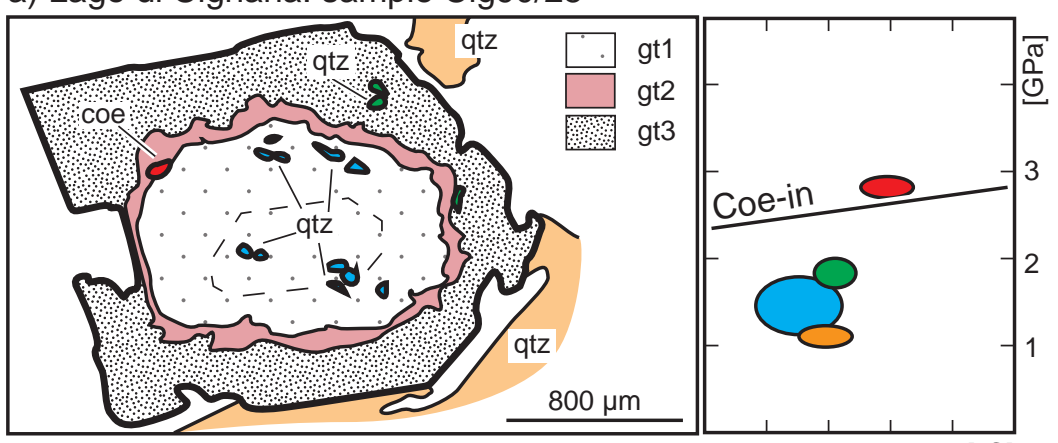

b) Adula - Cima di Gagnone
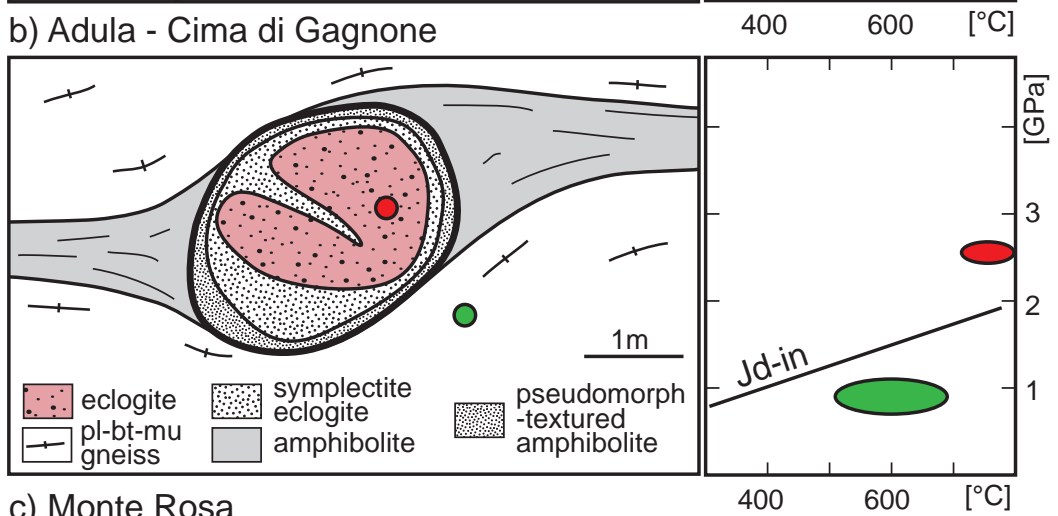

c) Monte Rosa

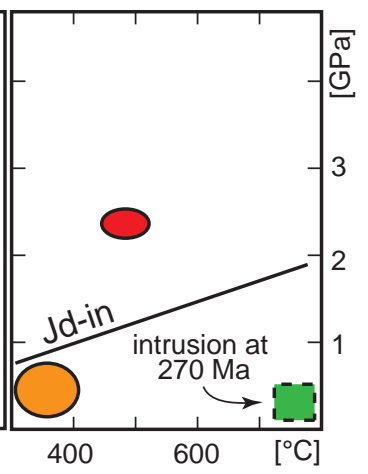

d) Dora Maira

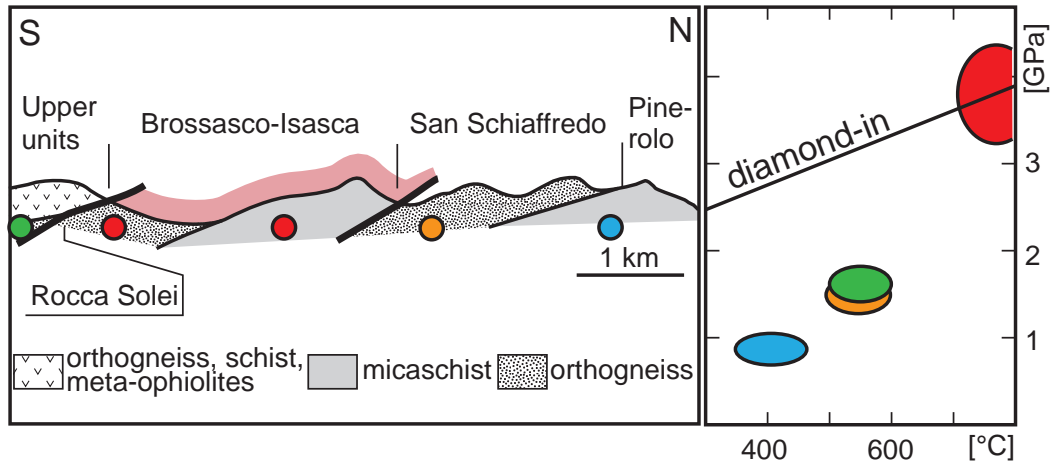




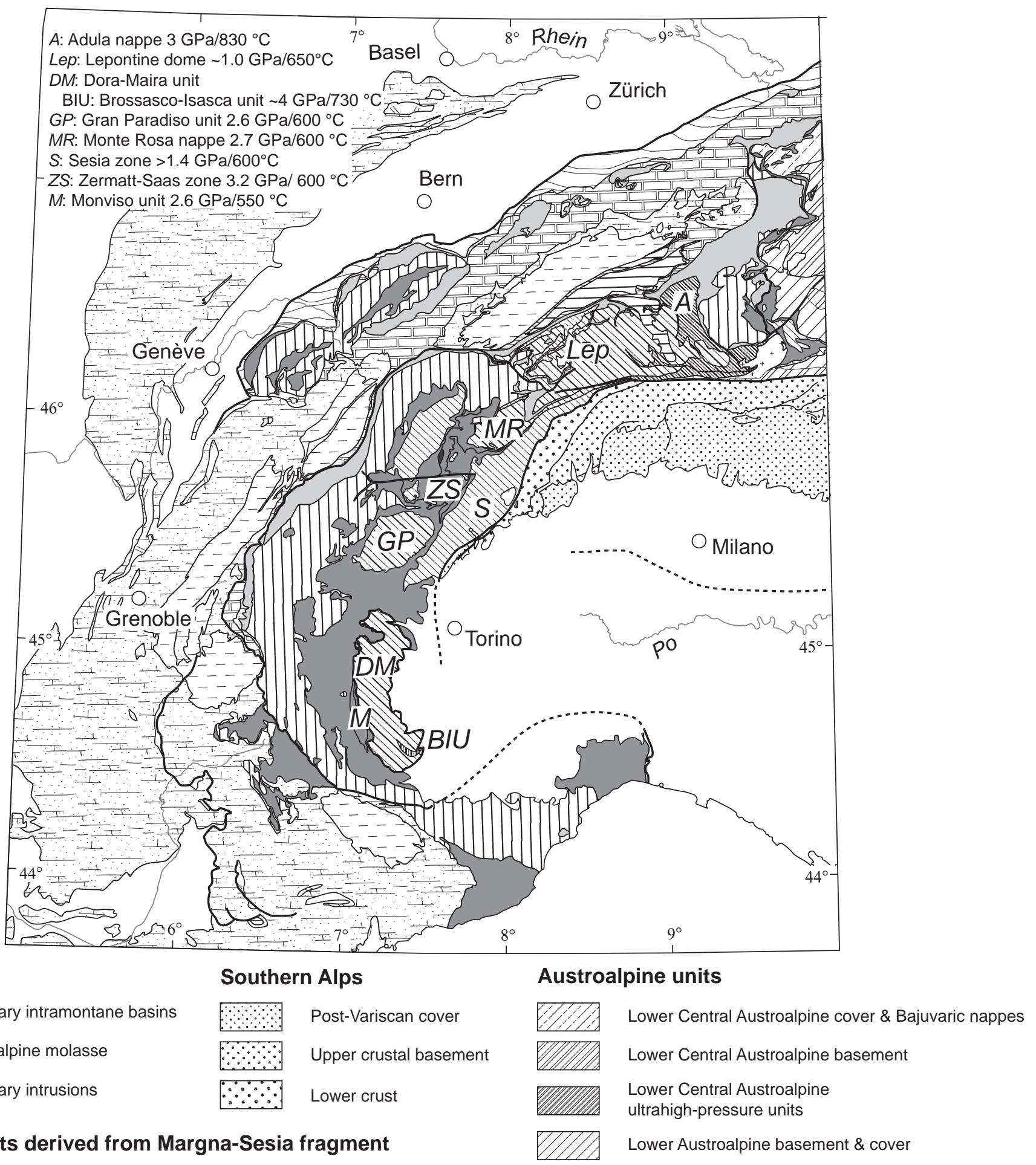

\section{Units derived from Margna-Sesia fragment}

\section{Upper Penninic units}

Ultrahigh-pressure-bearing units

Middle Penninic units

Lower Penninic units

Subpenninic units

Min Mesozoic cover

MIIV Basement

||||||||||| Ultrahigh-pressure-bearing units
Helvetic and Ultrahelvetic units, external massifs

Helvetic/Ultrahelvetic cover nappes

(Par)autochthonous cover of external massifs and Jura mountains

External massifs

Ultrahelvetic parautochthonous cover

Ultrahelvetic basement 





a) simplified geological map of the Zermatt Saas-Fee zone

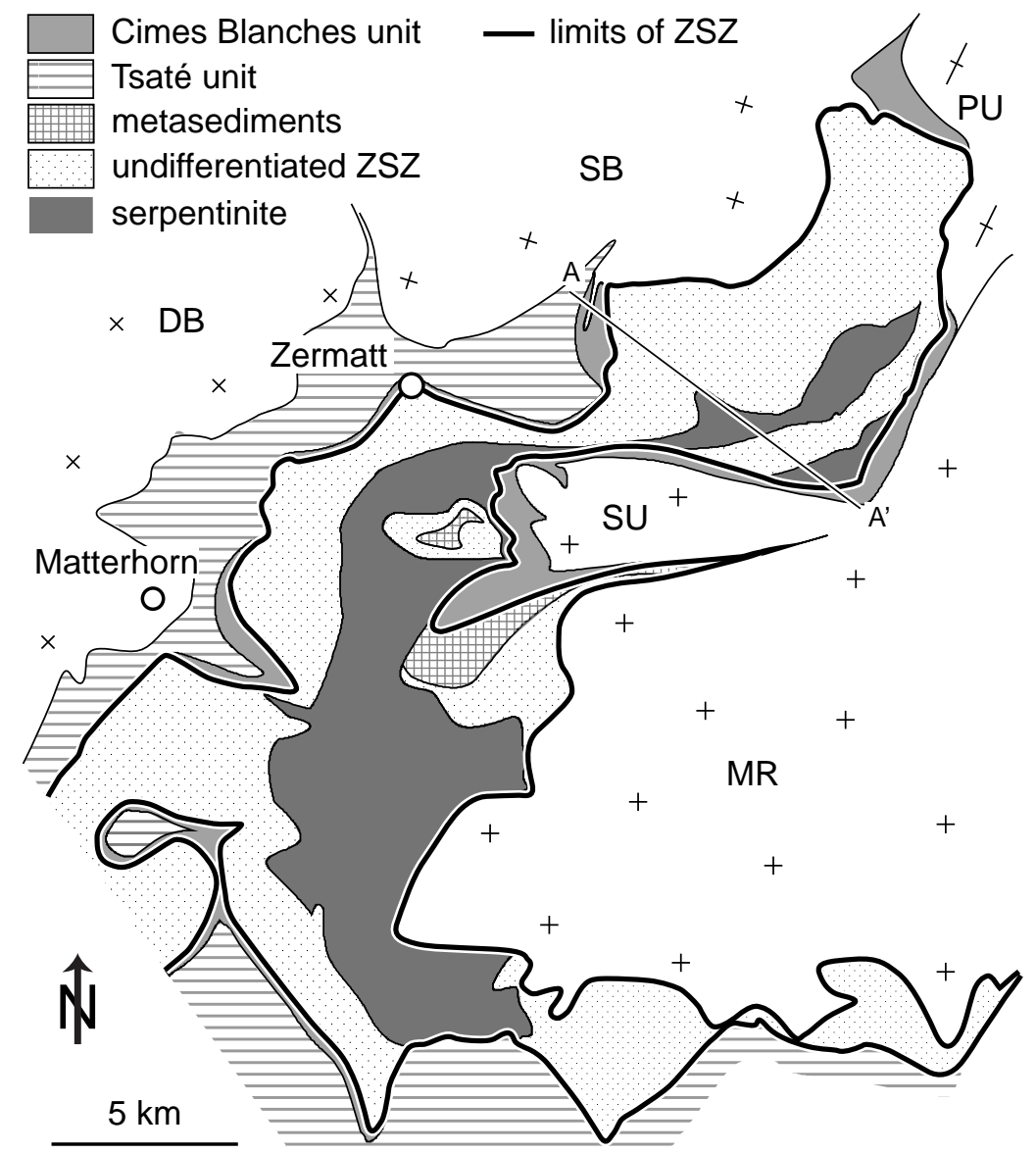

b) geological map in the Täsch Valley

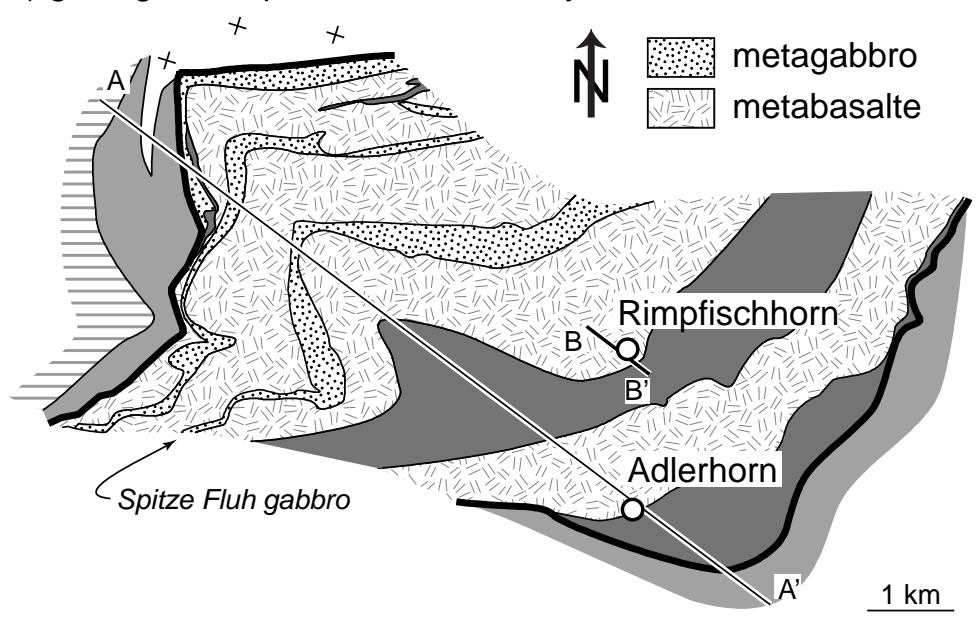

c) profile A-A' and B-B' along the traces shown in a) and b) NW

A

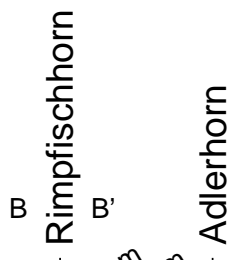

SE

$A^{\prime}$

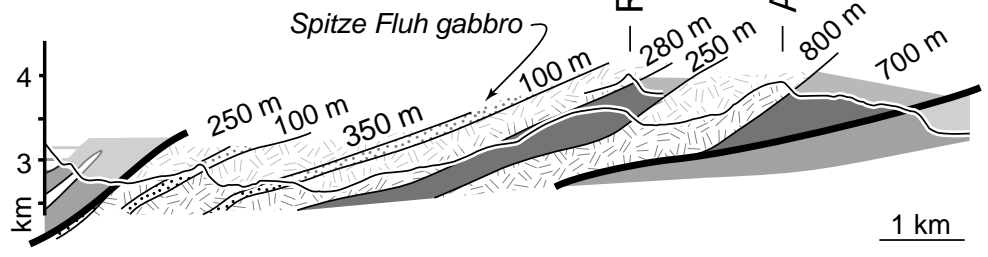

d) Spitze Fluh Flasergabbro

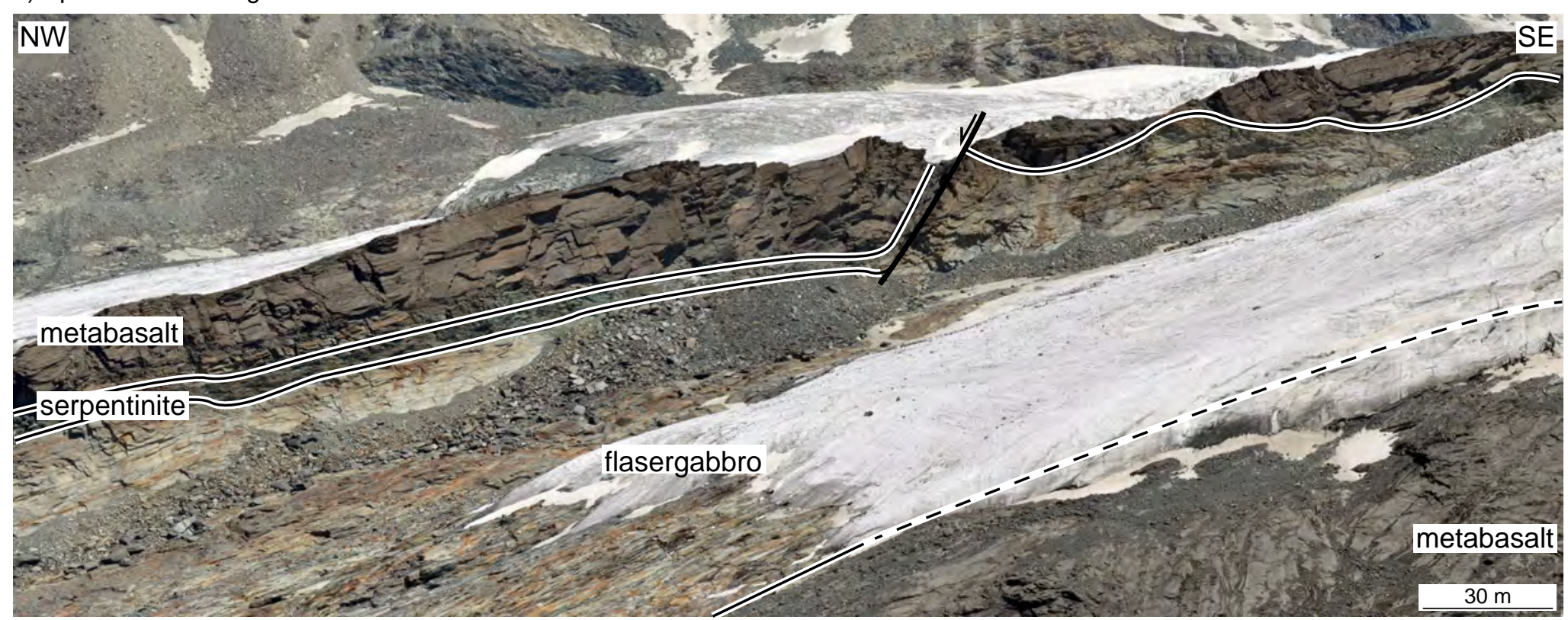


a) end-member 1: continous oceanic crust

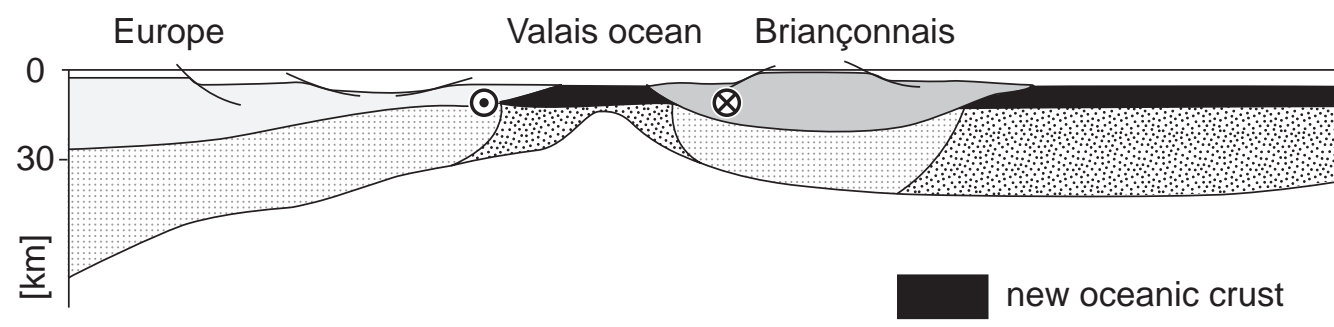

Piemonte-Liguria ocean

b) end-member 2: hyper-extended margins shown in c)
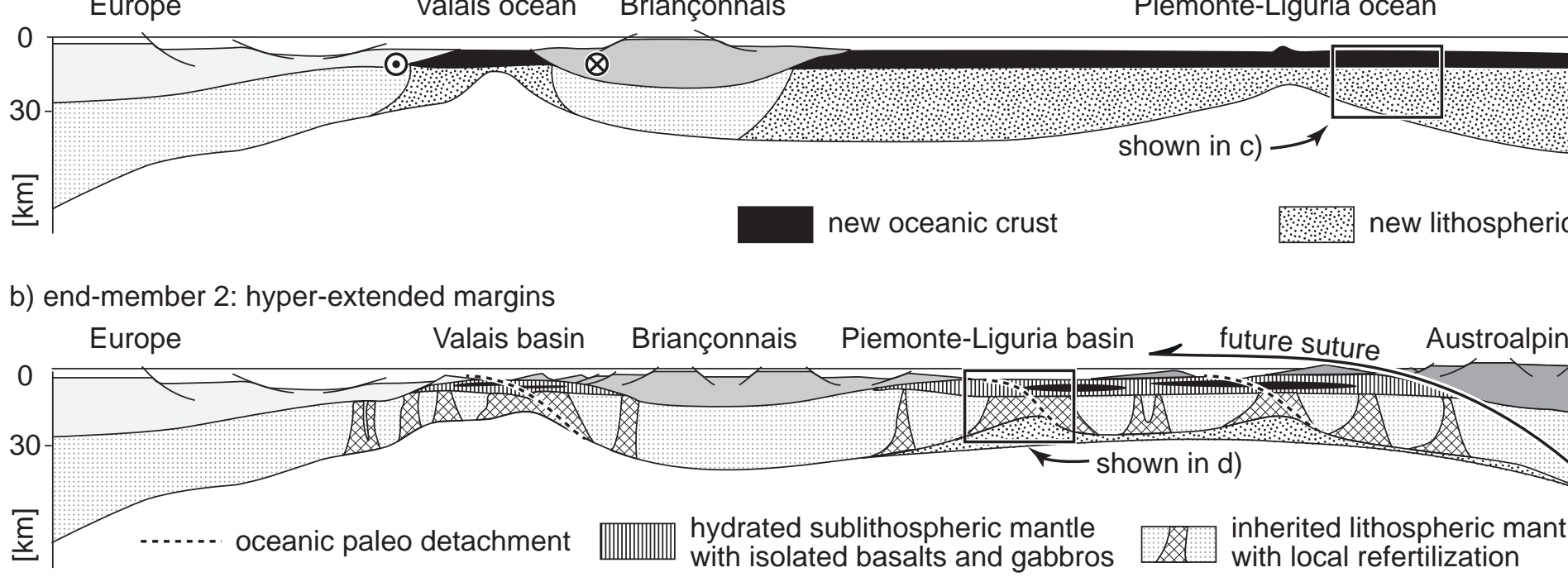

_ future suture
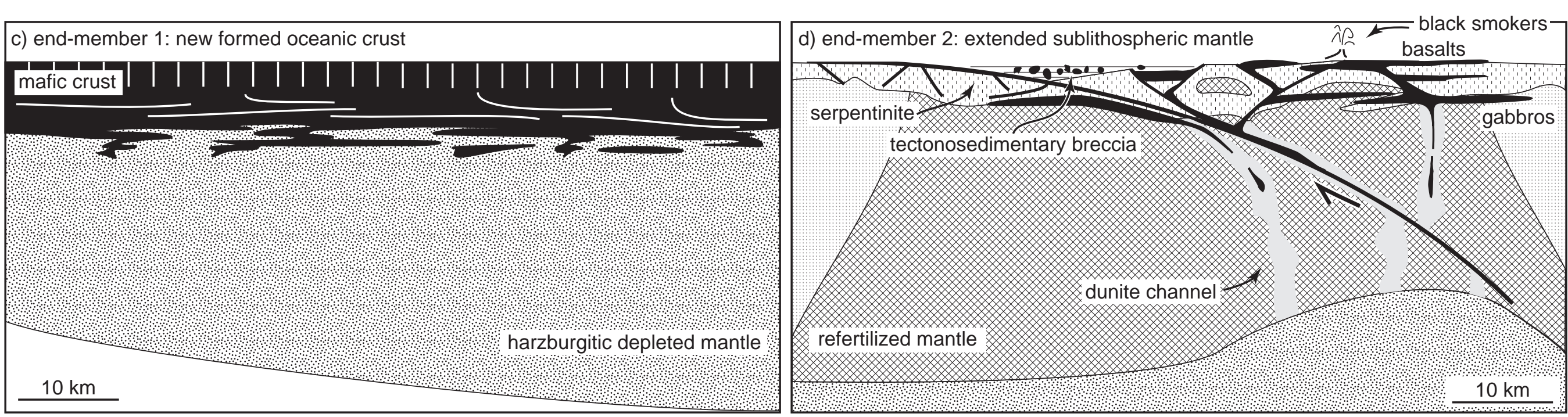

$\sim 110 \mathrm{Ma}$

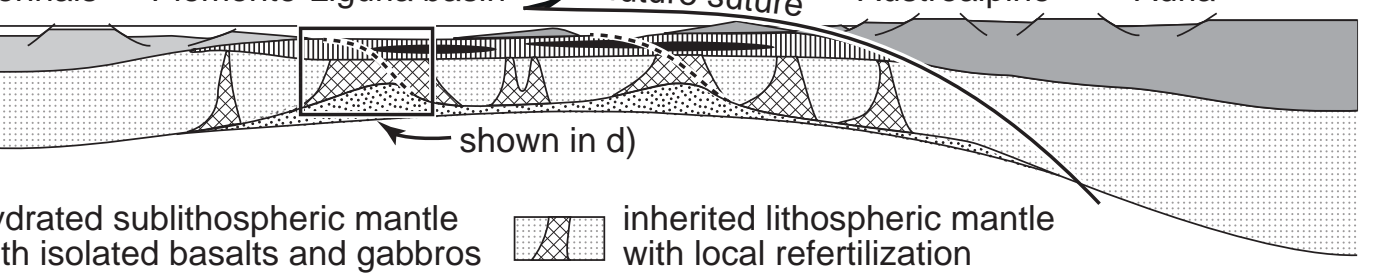




\section{Mineral and density isochemical pressure-temperature sections of the Brossasco-Isasca metagranite}

Representative bulk rock composition according to Ferrando et al., 2009

The rock is a metapelite with a medium-grained, garnet-kyanite-quartz/(coesite) + (jadeite) + high-Si phengite schist with accessory rutile and apatite.

$\mathrm{H}_{2} \mathrm{O}$ saturated,

Rock composition [wt\%]: $\mathrm{SiO}_{2}=73.2, \mathrm{Al}_{2} \mathrm{O}_{3}=13.5, \mathrm{FeO}=1.82, \mathrm{MnO}=0.05, \mathrm{MgO}=0.33, \mathrm{CaO}=0.9, \mathrm{Na}_{2} \mathrm{O}=2.74, \mathrm{~K}_{2} \mathrm{O}=5.18$
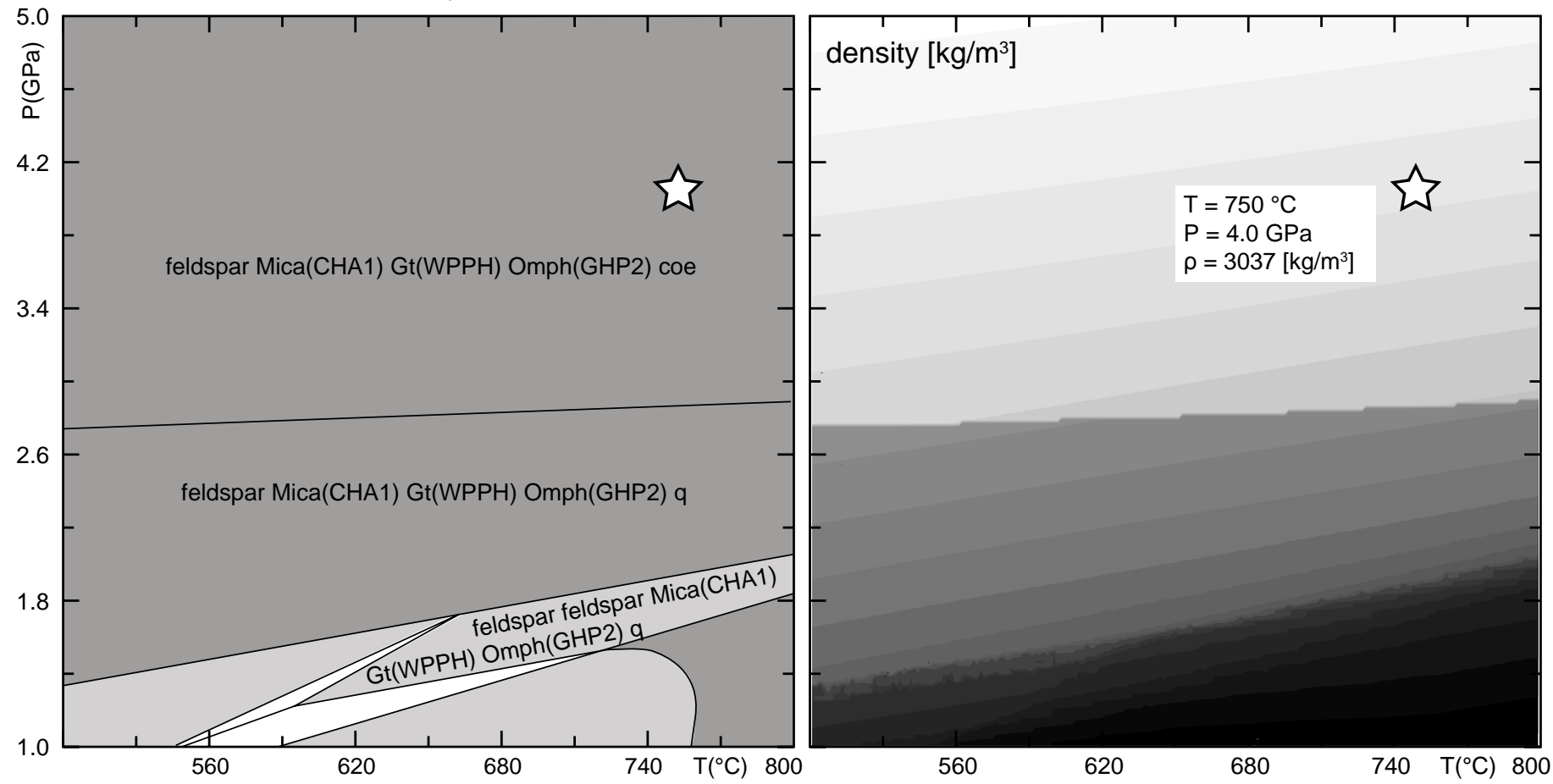

\section{Mineral and density isochemical pressure-temperature sections of the Brossasco-Isasca micaschist}

Bulk rock composition according to Groppo et al., 2006

The rock is a metapelite with a medium-grained, garnet-kyanite-quartz/(coesite) + (jadeite) + high-Si phengite schist with accessory rutile and apatite.

\section{$\mathrm{H}_{2} \mathrm{O}$ saturated}

Rock composition [wt\%]: $\mathrm{SiO}_{2}=49.81, \mathrm{TiO}_{2}=1.09, \mathrm{Al}_{2} \mathrm{O}_{3}=27.78, \mathrm{FeO}=9.42, \mathrm{MnO}=0.05, \mathrm{MgO}=2.28, \mathrm{CaO}=0.05, \mathrm{Na}_{2} \mathrm{O}=1.79, \mathrm{~K}_{2} \mathrm{O}=4.26$
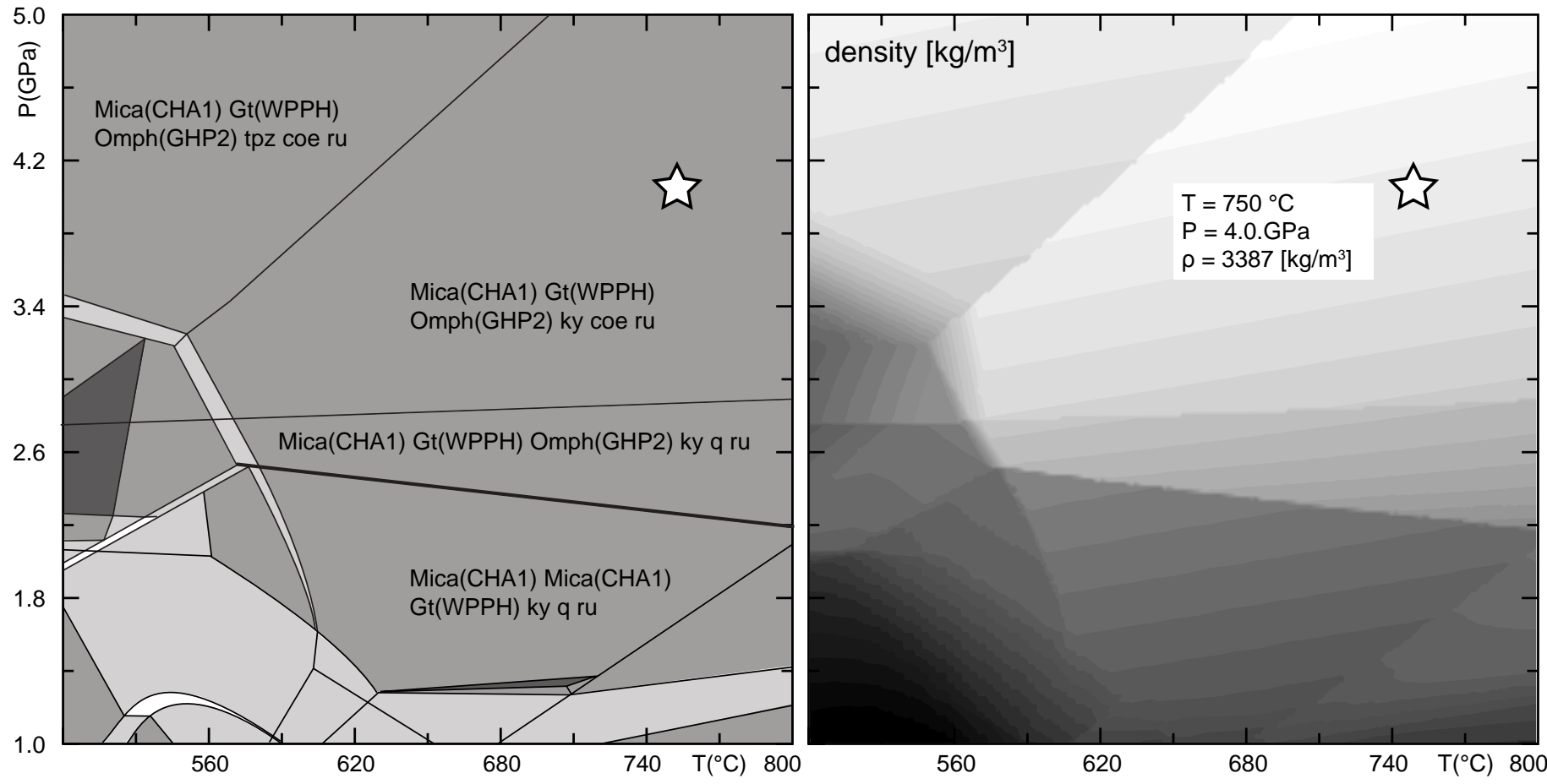

Abbreviation of minerals and solid solutions in http://www.perplex.ethz.ch/

\section{REFERENCES}

Ferrando, S., Frezzotti, M. L., Petrelli, M. \& Compagnoni, R., 2009. Metasomatism of continental crust during subduction: the UHP whiteschists from the Southern Dora-Maira Massif (Italian Western Alps). Journal of Metamorphic Geology, 27, 739-756

Groppo, C., Castelli, D., Compagnoni, R. 2006. Late chloritoid-staurolite assemblage in a garnet-kyanite-bearing metapelite from the ultrahigh-pressure Brossasco-Isasca unit (Dora-Maira Massif, Western Alps): New petrological constraints for a portion of the decompressional path.Geological Society of America Special Papers, 403, 127-138 


\section{Mineral and density Isochemical pressure-temperature sections of the Zermatt Saas zone}

a) Bulk rock composition and peak conditions according to Bucher, 2005

The rock is a chloritoid-glaucophane-epidote-garnet-omphacite-talc-metabasalt

$\mathrm{H}_{2} \mathrm{O}$ saturated

Rock composition [wt\%] used: $\mathrm{SiO}_{2}=47.52, \mathrm{Al}_{2} \mathrm{O}_{3}=16.92, \mathrm{FeO}=7.488, \mathrm{Fe}_{2} \mathrm{O}_{3}=2.084, \mathrm{MgO}=9.53, \mathrm{CaO}=5.23, \mathrm{Na}_{2} \mathrm{O}=4.95$
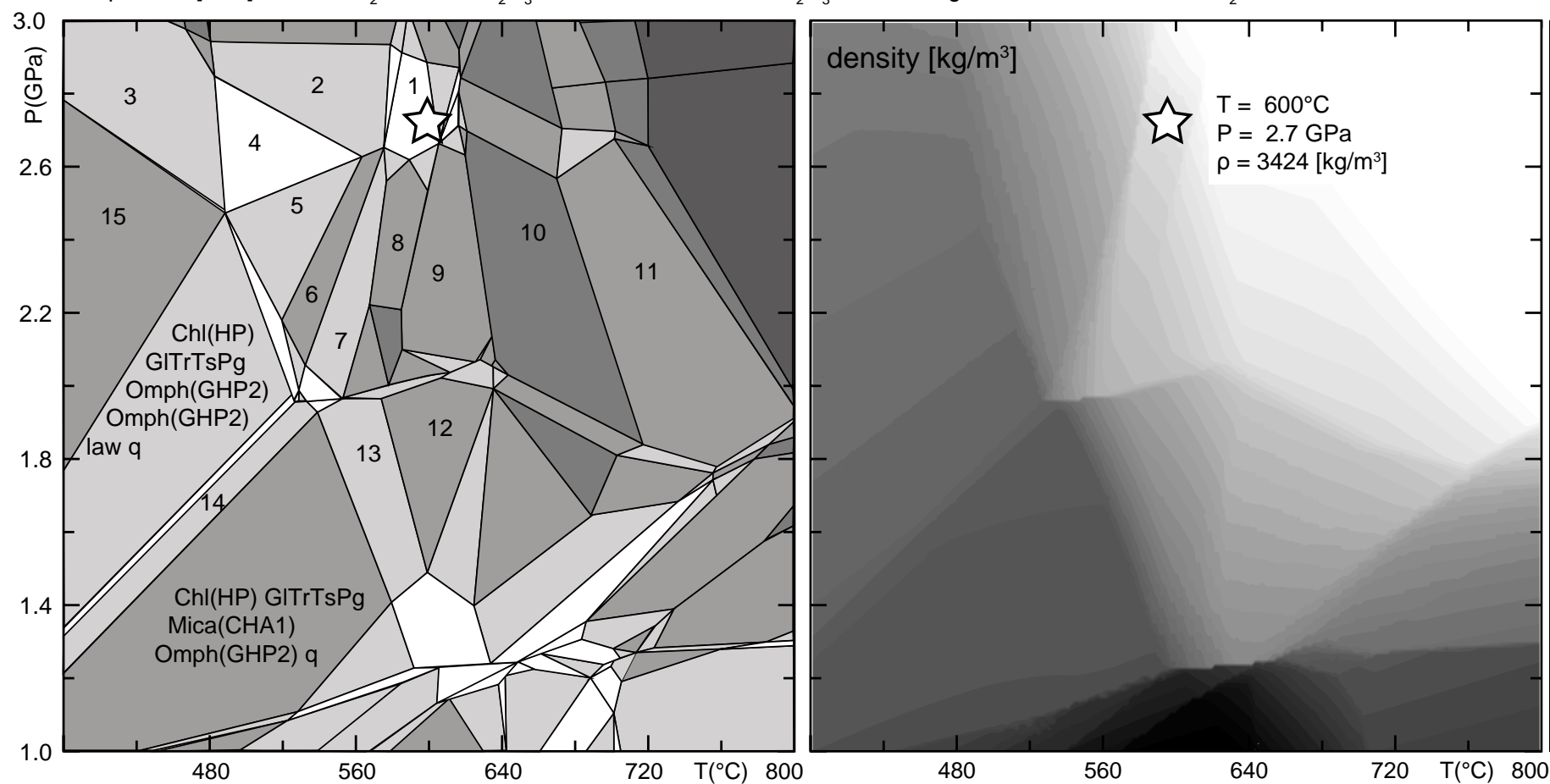

1) T GITrTsPg Ctd(SGH) Gt(WPPH) Omph(GHP2) Omph(GHP2) law

2) $\mathrm{Chl}(\mathrm{HP}) \mathrm{T}$ GITrTsPg Gt(WPPH) Omph(GHP2) law

9) GITrTsPg Ctd(SGH) Gt(WPPH) Omph(GHP2) ky

10) GITrTsPg Gt(WPPH) Omph(GHP2) ky

3) Chl(HP) T GITrTsPg Omph(GHP2) Omph(GHP2) law

11) GITrTsPg Gt(WPPH) Omph(GHP2) ky q

4) Chl(HP) T GITrTsPg Gt(WPPH) Omph(GHP2) Omph(GHP2) law

5) $\mathrm{Chl}(\mathrm{HP}) \mathrm{GITrTsPg}$ Gt(WPPH) Omph(GHP2) Omph(GHP2) law

12) Chl(HP) GITrTsPg Mica(CHA1) Gt(WPPH) Omph(GHP2)

13) Chl(HP) GITrTsPg Mica(CHA1) Gt(WPPH) Omph(GHP2) q

14) Chl(HP) GITrTsPg Mica(CHA1) Omph(GHP2) law $q$

6) Chl(HP) GITrTsPg Gt(WPPH) Omph(GHP2) law

7) $\mathrm{Chl}(\mathrm{HP}) \mathrm{GlTrTsPg} \mathrm{Ctd}(\mathrm{SGH}) \mathrm{Gt}(\mathrm{WPPH})$ Omph(GHP2) law

8) GITrTsPg Ctd(SGH) Gt(WPPH) Omph(GHP2) law

15) $\mathrm{Chl}(\mathrm{HP}) \mathrm{GITrTsPg} \mathrm{Omph}(\mathrm{GHP} 2)$ Omph(GHP2) law

b) Bulk rock composition and peak conditions according to Ganguin, 1988

The rock is a omphacite-garnet-chloritoid-talc-zoisite-metagabbro

$\mathrm{H}_{2} \mathrm{O}$ saturated

Rock composition [wt\%] used: $\mathrm{SiO}_{2}=48.29, \mathrm{Al}_{2} \mathrm{O}_{3}=18.87, \mathrm{FeO}=2.32, \mathrm{Fe}_{2} \mathrm{O}_{3}=1.90, \mathrm{MgO}=10.29, \mathrm{CaO}=12.30, \mathrm{Na}_{2} \mathrm{O}=3.03$

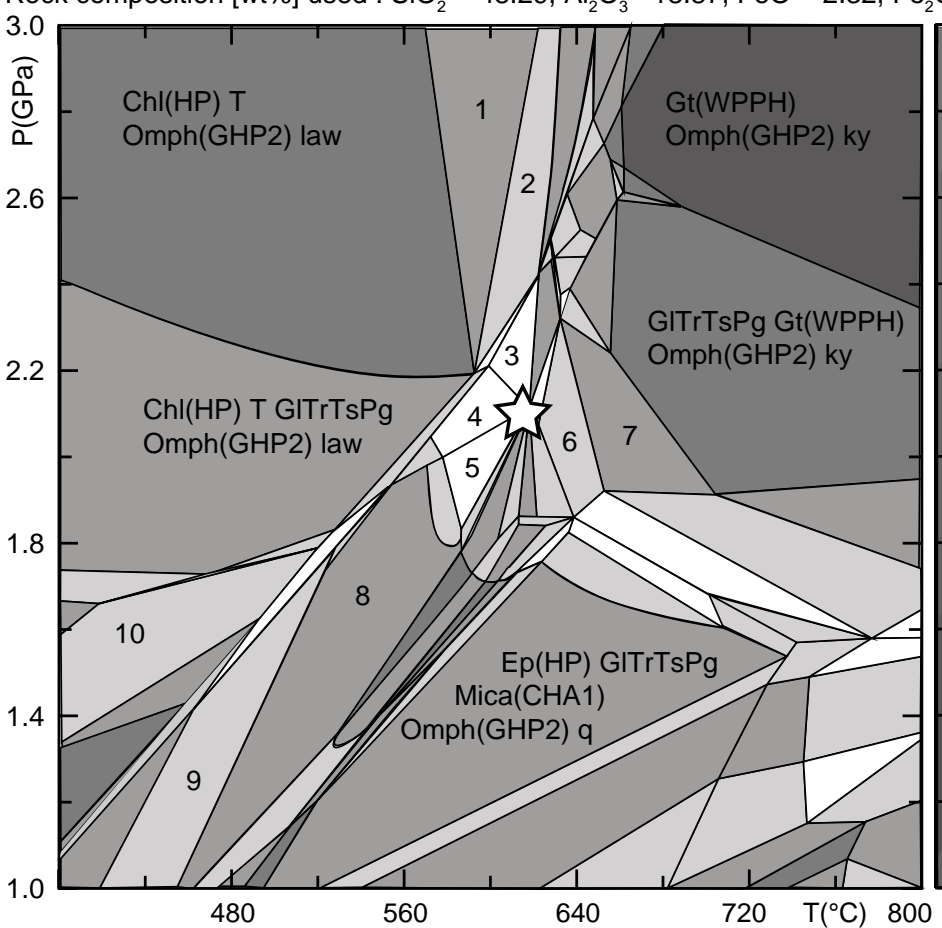

1) $\mathrm{Chl}(\mathrm{HP}) \mathrm{T} \mathrm{Gt}(\mathrm{WPPH}) \mathrm{Omph}(\mathrm{GHP} 2)$ law

2) $\mathrm{Chl}(\mathrm{HP}) \mathrm{T} \mathrm{Ctd}(\mathrm{SGH}) \mathrm{Gt}(\mathrm{WPPH}) \mathrm{Omph}(\mathrm{GHP} 2)$ law

3) $\mathrm{Chl}(\mathrm{HP}) \mathrm{Ep}(\mathrm{HP}) \mathrm{T} \mathrm{Gt}(\mathrm{WPPH}) \mathrm{Omph}(\mathrm{GHP} 2) \mathrm{ky} \mathrm{zo}$

4) $\mathrm{Chl}(\mathrm{HP}) \mathrm{Ep}(\mathrm{HP}) \mathrm{T}$ GITrTsPg Gt(WPPH) Omph(GHP2) zo

5) Chl(HP) Ep(HP) GITrTsPg GITrTsPg Gt(WPPH) Omph(GHP2) zo

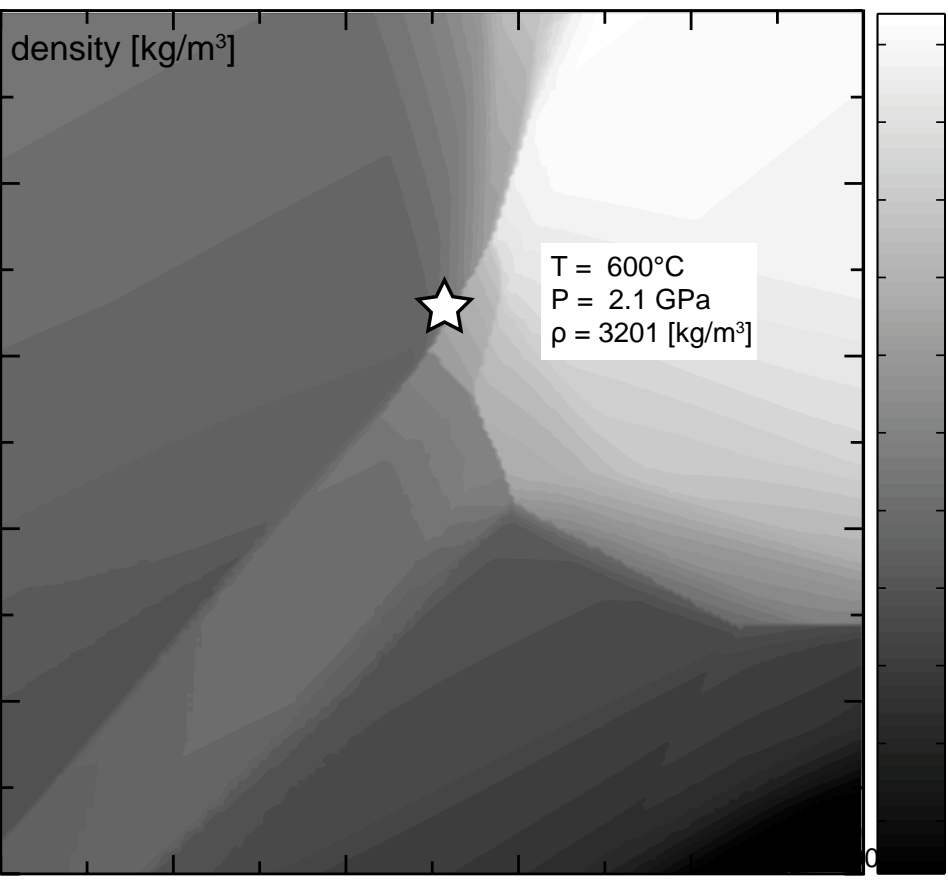

Abbreviation of minerals and solid solutions in http://www.perplex.ethz.ch/

\section{REFERENCES}

Bucher, K., 2005. Blueschists, eclogites, and decompression assemblages of the Zermatt-Saas ophiolite: High-pressure metamorphism of subducted Tethys lithosphere. American Mineralogist, 90, 821-835.

Ganguin, J., 1988. Contribution à la caracterisation du métamorphisme polyphase de la zone de Zermatt-Saas Fee (Alpes Valaisannes), Thèse ETHZ N 8731 , Zürich

6) $\mathrm{Ep}(\mathrm{HP}) \mathrm{GITrTsPg} \mathrm{Gt}(\mathrm{WPPH}) \mathrm{Omph}(\mathrm{GHP} 2) \mathrm{ky} \mathrm{zo}$

7) GITrTsPg Gt(WPPH) Omph(GHP2) ky zo

8) Chl(HP) Ep(HP) GITrTsPg GITrTsPg Omph(GHP2)

9) $\mathrm{Chl}(\mathrm{HP}) \mathrm{Ep}(\mathrm{HP}) \mathrm{GITrTsPg}$ GITrTsPg Omph(GHP2) q

10) Chl(HP) GITrTsPg GITrTsPg Omph(GHP2) law $q$ 